\title{
Linarin, a Glycosylated Flavonoid, with Potential Therapeutic Attributes: A Comprehensive Review
}

\author{
Javad Mottaghipisheh ${ }^{1, *(1)}$, Hadi Taghrir ${ }^{2}$ (), Anahita Boveiri Dehsheikh ${ }^{3}$, Kamiar Zomorodian ${ }^{4}$, Cambyz Irajie ${ }^{5}$, \\ Mohammad Mahmoodi Sourestani ${ }^{3}$ and Aida Iraji ${ }^{6,7, *}$
}

1 Center for Molecular Biosciences (CMBI), Institute of Pharmacy/Pharmacognosy, University of Innsbruck, Innrain 80-82, 6020 Innsbruck, Austria

2 Department of Medicinal Chemistry, Faculty of Pharmacy, Shiraz University of Medical Sciences, Shiraz 71468-64685, Iran; hadi_taghrir@yahoo.com

3 Department of Horticultural Science, Faculty of Agriculture, Shahid Chamran University of Ahvaz, Ahvaz 61357-43311, Iran; anahitaboveiri84@gmail.com (A.B.D.); m.mahmoodi@scu.ac.ir (M.M.S.)

4 Department of Medical Mycology and Parasitology, School of Medicine, Shiraz University of Medical Sciences, Shiraz 14336-71348, Iran; kzomorodian@gmail.com

5 Department of Medical Biotechnology, School of Advanced Medical Sciences and Technologies, Shiraz University of Medical Sciences, Shiraz 71348-14336, Iran; irajie@sums.ac.ir

6 Central Research laboratory, Shiraz University of Medical Sciences, Shiraz 71348-14336, Iran

7 Stem Cells Technology Research Center, Shiraz University of Medical Sciences, Shiraz 71348-14336, Iran

* Correspondence: javad.mottaghipisheh@uibk.ac.at (J.M.); iraji@sums.ac.ir (A.I.)

check for

updates

Citation: Mottaghipisheh, J.; Taghrir,

H.; Boveiri Dehsheikh, A.;

Zomorodian, K.; Irajie, C.; Mahmoodi

Sourestani, M.; Iraji, A. Linarin, a

Glycosylated Flavonoid, with

Potential Therapeutic Attributes: A

Comprehensive Review.

Pharmaceuticals 2021, 14, 1104.

https://doi.org/10.3390/ph14111104

Academic Editor: Daniela De Vita

Received: 1 October 2021

Accepted: 25 October 2021

Published: 29 October 2021

Publisher's Note: MDPI stays neutral with regard to jurisdictional claims in published maps and institutional affiliations.

Copyright: (c) 2021 by the authors. Licensee MDPI, Basel, Switzerland. This article is an open access article distributed under the terms and conditions of the Creative Commons Attribution (CC BY) license (https:/ / creativecommons.org/licenses/by/ $4.0 /)$.

\begin{abstract}
Many flavonoids, as eminent phenolic compounds, have been commercialized and consumed as dietary supplements due to their incredible human health benefits. In the present study, a bioactive flavone glycoside linarin (LN) was designated to comprehensively overview its phytochemical and biological properties. LN has been characterized abundantly in the Cirsium, Micromeria, and Buddleja species belonging to Asteraceae, Lamiaceae, and Scrophulariaceae families, respectively. Biological assessments exhibited promising activities of LN, particularly, the remedial effects on central nervous system (CNS) disorders, whereas the remarkable sleep enhancing and sedative effects as well as AChE (acetylcholinesterase) inhibitory activity were highlighted. Of note, LN has indicated promising anti osteoblast proliferation and differentiation, thus a bone formation effect. Further biological and pharmacological assessments of LN and its optimized semi-synthetic derivatives, specifically its therapeutic characteristics on osteoarthritis and osteoporosis, might lead to uncovering potential drug candidates.
\end{abstract}

Keywords: flavonoids; linarin; chemotaxonomy; phytochemistry; bioactivities

\section{Introduction}

The application of plants for medicinal purposes is as old as humanity itself. Since many of them are considered as functional foods and extensively consumed in folk medicine, their biological and phytochemical assessments are pivotal attitudes [1,2]. By developing human knowledge, the study of plant constituents has led to the discovery of secondary metabolites (phytochemicals) as the major compounds responsible for the bioactivities. These biosynthesized compounds (both volatile and non-volatile) mostly possess defensive roles in plants to assist surviving them against abiotic and biotic stressors [3,4].

Investigation of phytoconstituents has been the target of many researchers in order to determine their health benefits. So far, many phytochemicals have been developed and consumed as successful drugs for the treatment of a diverse range of ailments and disorders, specifically cancer types [5-7]. Among the varied phytochemical classifications, flavonoids have been introduced as one of the largest natural phenolic compounds with broad valuable biological properties [8,9]. Based on the chemical structures, these compounds are divided into six main subclasses: flavones, flavanones, flavonols, flavan-3-ols, isoflavones, and 
anthocyanins $[10,11]$. Even though the phytochemical and biological characteristics of these compounds are being studied $[11,12]$, they are still interesting target molecules to be explored.

Linarin (syn. acacetin 7-O-rhamnosyl( $\left.1^{\prime \prime \prime} \rightarrow 6^{\prime \prime}\right)$ glucoside, or acacetin 7-O-rutinoside), as a glycosylated flavone (Figure 1), has been identified from various plant species mainly belonging to the Asteraceae and Lamiaceae families. Regarding the potent bioactivities of this flavonoid reported by several experiments, and the importance of flavonoid consumption as drugs and/or supplements, the present study aims at comprehensively collecting all the phytochemical (i.e., chemotaxonomy and phytochemistry) and biological reports of this flavonoid.<smiles>COc1ccc(-c2cc(=O)c3c(O)cc(O[C@@H]4O[C@H](CO[C@H]5O[C@@H](C)[C@@H](O)[C@H](O)[C@H]5O)[C@@H](O)[C@H](O)[C@H]4O)cc3o2)cc1</smiles>

Figure 1. The chemical structure of linarin.

The scientific databases including Web of Science, SciFinder, and PubMed were used to find the correlated data by utilizing the keyword of "linarin" within the English-language papers (access date: 25 May 2021).

\section{Phytochemistry and Chemotaxonomy of Linarin}

So far, among the 13 plant families containing linarin (LN), Asteraceae and Lamiaceae have been identified as the richest ones. The most LN contents have been reported in various Cirsium spp.; however, this compound has also been isolated from the genus Micromeria and Buddleja belonging to Lamiaceae and Scrophulariaceae, respectively. This glycosylated flavone has mainly been isolated and characterized from alcoholic (methanolic and ethanolic) and hydro-alcoholic extracts. In the following sections, the available data on the phytochemistry of this compound are discussed in detail (Tables S1 and S2).

\subsection{Isolation of Linarin from Plant Species}

\subsubsection{Asteraceae}

LN has been isolated from diverse parts of Cirsium spp. By utilizing column chromatography on silica gel (CC) as the final separation step, this compound has been isolated from the methanolic extract of $C$. arvense aerial parts [13]. From the roots of $C$. arvense subsp. vestitum via application of vacuum column chromatography [14], and flowers of C. canum (L.) using reverse-phase high-performance liquid chromatography (RP-HPLC), LN has been isolated [15].

C. japonicum can be considered as one of the richest plant species of LN. Sephadex ${ }^{\circledR} \mathrm{LH}-$ 20 (SLH) has been applied to the isolation or purification of many flavonoid derivatives [12]. This technique has been employed to isolate LN from the aerial parts of $C$. japonicum [16].

Zhang et al. (2018) isolated LN from C. japonicum [17]; in addition, liquid chromato graphy-mass spectrometry (LC-MS/MS) was implemented to characterize it from the hydro-ethanolic (70\%) extract [18]. Preparative-HPLC has been exploited to isolate LN from the ethanolic fraction of $C$. japonicum var. maackii [19]. Moreover, the methanolic extract of $C$. japonicum var. ussuriense (Regel) Kitam. ex Ohwi obtained from the aerial parts 
has been subjected to isolate $\mathrm{LN}$ by applying the solvent system of $\mathrm{CHCl}_{3}-\mathrm{MeOH}-\mathrm{H}_{2} \mathrm{O}$ $(25: 8: 5)$ in CC on silica gel [20].

LN has been isolated from three other Cirsium species: from the leaf and flower methanolic extract of $C$. rivulare using preparative-HPLC [21]; from the flower methanolic fraction of C. setidens applying CC on Silica gel [22]; and from the aerial arts using liquid chromatography (LC) [23] and hydro-ethanolic extracts of C. setosum (Willd.) MB. (utilizing HPLC) [24]; however, LN has also been identified from the ethanolic extract of this species by applying ultra-performance liquid chromatography-mass spectrometry (UPLC-MS) [25].

Chrysanthemum species are considered as one of the major sources of LN. It has been isolated from the methanolic extracts of Chrysanthemum boreale (Makino) Makino flowers by utilizing CC on silica [26,27], and the hydro-ethanolic (95\%) fractions obtained from the Chrysanthemum morifolium Ramat flowers [28].

C. indicum, famed as "Ye Ju Hua" in China, has a long history in the treatment of inflammation, hypertension, and respiratory diseases in traditional Chinese and Korean medicine; furthermore, it is traditionally used in tea preparations, tinctures, creams, and lotions [29].

This plant species (C. indicum) has been implemented to isolate LN conducted by several studies. It has also been isolated from its flower, using mostly CC on silica gel [30-33], from the dichloromethane extracts of aerial part and methanolic soluble-fraction of the whole part via application of CC on silica gel [34,35].

The purification of LN was also carried out by the solid-liquid extraction method from the hydroethanolic $(75 \%)$ extract of the same plant species through utilization of various solvents including petroleum ether, ethyl acetate, ethanol, and water [36]. The whole herb and its aerial parts of $C$. zawadskii var. latilobum (Maxim.) Kitam. has been reported to possess LN, whereas CC on silica gel was used [37,38].

In the study of Li et al. (2016), high-speed counter-current chromatography (HSCCC) was applied in order to isolate this flavonoid from the hydro-ethanolic extract $(80 \%)$ of Flos Chrysanthemi indici [39], however, it has also been identified from this species as reported by three other groups [40-42].

The whole part methanolic extract of Artemisia capillaris Thunb. has been chromatographed by $\mathrm{CC}$ on silica gel using $\mathrm{CH}_{2} \mathrm{Cl}_{2}-\mathrm{MeOH}$ (20:1) as solvent systems leading to isolate LN [43]; moreover, this compound was identified in a rare species Picnomon acarna (L.) Cass., where its aerial parts were separated in CC [44].

\subsubsection{Lamiaceae}

Lamiaceae (syn. Labiatae), a large plant family consisting of perennial or annual herbaceous plants and shrubs, is majorly known for their aromatic characteristics [45]. Various genus belonging to this family are considered as natural flavonoid sources including LN. Among them, different species of Mentha, Micromeria, and Satureja can be mentioned.

LN has previously been isolated from the hydro-methanolic (80\%) extracts of the flower [46] and aerial parts [47] of Mentha arvensis L.; however, it has been reported in M. haplocalyx Briq. in the ethyl acetate extracts of the aerial parts of three other Mentha species comprising M. spicata, M. piperita, and M. villosonervata, where CC on silica gel was applied as the final chromatography step [48].

Dai et al. (2008) isolated LN from a hydro-ethanolic (75\%) soluble-fraction of Dracocephalum peregrinum $\mathrm{L}$. aerial parts by hiring extensive chromatographic techniques [49]. This flavone has previously been isolated and characterized from other following species: ethanolic extract of Leonurus japonicus Houtt. aerial parts (via CC on silica gel $\mathrm{CH}_{2} \mathrm{Cl}_{2}-$ $\mathrm{MeOH}$ (100:1-0:100) [50] as well as the leaves of methanolic extracts of Calamintha officinalis Moench [51] and Calamintha glandulosa (Req.) Benth. [52], where in the later study, semiprepHPLC was utilized as the final separation step by using $\mathrm{H}_{2} \mathrm{O}-\mathrm{ACN}$ (50 to $100 \%$ ). LN has further been reported in the Ziziphora clinopodioides Lam. herb methanolic extract [53]. 


\subsubsection{Scrophulariaceae}

The plants belonging to Scrophulariaceae can be considered as the third natural source of LN. Among them Buddleja spp. are the richest ones. Previously, from the leaf methanolic extract of Buddleja davidii Franch., LN was isolated by the utilization of centrifugal partition chromatography (CPC) and the solvent system of $\mathrm{CHCl}_{3}-\mathrm{MeOH}_{-} \mathrm{H}_{2} \mathrm{O}$ (45:33:22) [54]. ElDomiaty et al. (2009) also purified LN from the whole part hydro-ethanolic (95\%) extract of Buddleja asiatica Lour., while CC on silica gel was used to separate it [55].

Buddleja cordata Kunth was subjected to isolate its phytoconstituents and LN was isolated and characterized from the leaves [56] and whole parts [57]. In three other investigations, $\mathrm{LN}$ was isolated from mostly alcoholic extracts of the flowers of Buddleja officinalis Maxim [58-60]. CC on silica gel using $\mathrm{CHCl}_{3}-\mathrm{MeOH}$ with ratios of 19:1, 9:1, 8:2 were applied to isolate LN from the aerial parts of Buddleja scordioides Kunth [61]. This compound was isolated from two Linaria species L. japonica, L. vulgaris, and L. kurdica subsp. eriocaly, while the whole parts were chromatographed [62-64].

\subsubsection{Miscellaneous Plants}

LN has been isolated from the whole part methanolic extract of Exacum macranthum Arn. ex Griseb. (Gentianaceae) via the recrystallization method [65]. This phytochemical has also been isolated and identified from Lobelia chinensis Lour. (Campanulaceae) [66], Ginkgo biloba L. (Ginkgoaceae) [67], Bombax malabaricum DC. (Malvaceae) [68], Avena sativa L.(Poaceae) [69], Thalictrum aquilegiifolium L. [70], and Coptis chinensis Franch [71] (Ranunculaceae), Zanthoxylum affine Kunth (Rutaceae) [72] and Lippia rubella (Moldenke) T.R.S.Silva \& Salimena (Verbenaceae) [73].

\subsection{Quantification and Qualification Analysis of Linarin in Plants}

By utilization of extensive analytical methods, LN has been qualified and quantified in plant species. So far, the plants belonging to Asteraceae, Lamiaceae, Scrophulariaceae, and Valerianaceae have been reported to be rich in LN content. Table S2 comprehensively lists all the information regarding the fingerprinting analysis of this compound throughout the plant species, however, the following sections describe them in brief.

\subsubsection{Asteraceae}

Plants in the Asteraceae family, particularly Cirsium spp. and Chrysanthemum spp., have been characterized as the richest herbal sources of LN. It has been identified throughout six species of the Cirsium genus; HPLC coupled to an ultraviolet (UV) detector was used to qualify this compound in the methanolic extract of $C$. arvense [13], along with the report by Demirta et al. (2017), which quantified LN from its root via HPLC-MS (MicroTOF-Q) [14].

The LN content of various soluble-fraction extracted from the flower part of Cirsium canum (L.) All. has formerly been analyzed by HPLC-DAD (HPLC-diode array detector). Consequently, the hydro-methanolic $(50 \%)$ and dichloromethane extracts possessed the highest and lowest contents with 121.75 and $1.94 \mu \mathrm{g} / \mathrm{g}$, respectively [15].

Cirsiumjaponicum (Thunb.) Fisch. ex DC., Japanese field thistle, is renowned in Chinese pharmacopeia for the treatment of inflammation and bleeding [16] as well as application in Korean folk medicine as a uretic as well as antihemorrhagic and antihepatitic medication [74]. Nonetheless, Ganzera et al. (2005) analyzed pectolinarin as the main phytoconstituent of the C. japonicum methanolic aerial part extract, and LN was also quantified with a significant content of $0.26-1.15 \mathrm{mg} / 100 \mathrm{~g}$ through different plant samples by employing HPLC-MS [16].

From the alcoholic extracts of two different $C$. japonicum varieties (C. japonicum var. maackii Maxim and C. japonicum var. ussuriense (Regel) Kitam. ex Ohwi), LN was detected by employing HPLC-UV $[19,20]$. Moreover, the mixture of LN and pectolinarin was compared with the methanolic extracts obtained from the leaf $(170 \mathrm{mg} / \mathrm{g})$ and flower $(20 \mathrm{mg} / \mathrm{g})$ parts of Cirsium rivulare (Jacq.) All., whereas HPLC-UV was utilized as the analytical tool [21]. 
The methanolic extract of Cirsiumsetidens(Dunn) Nakai was phytochemically analyzed through HPLC-UV and a significant LN concentration of $120.3 \mathrm{mg} / \mathrm{g}$ was measured [22].

Cirsiumsetosum (Willd.) Besser ex M.Bieb. has further been elaborated to possess phytochemical contents in four studies. The LN content range of $0.3-2 \mathrm{mg} / 100 \mathrm{~g}$ has been recorded through analysis with HPLC-MS [16]. The methanolic soluble partitions of Hemistepta lyrate (Bunge) Bunge flower extracted from different plant samples were analytically assessed, and LN was subsequently quantified $(0.06-4.26 \mathrm{mg} / \mathrm{g})$ [26].

In a comparative phytochemical analysis of the ethanolic extract obtained from the Chrysanthemum morifolium Ramat. flower, LN was qualified and quantified in three cultivars by using HPLC-DAD-ESI/MS with the contents ranging from 0.117 to $0.583 \mathrm{mg} / \mathrm{g}$ [28]. HPLC-DAD analysis of the Chrysanthemum zawadskii var. latilobum (Maxim.) Kitam. extract showed LN as the marker compound with a $22.8 \mathrm{mg} / \mathrm{g}$ extract [75].

Chrysanthemum indicum L., as an edible medicinal plant, is famed for its consumption as a food supplement and herbal tea. It has a diverse range of therapeutic applications, specifically in Chinese and Korean folk medicine, for the treatment of immune-related disorders, to heal several infectious diseases, and hypertension symptoms [31]. In several studies reporting its phytoconstituents, LN has also been characterized as the major compounds. He et al. (2016) qualified this compound in the flower methanolic extract via utilization of HPLC-DAD [31].

In a comparative investigation, the phytochemical content of different parts of $C$. ndicum dichloromethane extract was analyzed. As the result, the leaf extract contained the highest LN content $(1.47 \mathrm{~g} / 100 \mathrm{~g})$ compared to its stem and flower parts $(0.65 \mathrm{~g} / 100 \mathrm{~g})$ [35]. In a similar study, HPLC-MS application led to the fingerprinting analysis of various $C$. indicum parts collected from China; consequently, the root and flower parts indicated the highest and lowest LN amounts ( 0.344 and $0.052 \mu \mathrm{g} / \mathrm{mg}$ FW), respectively [34]. Furthermore, the hydro-ethanolic extract $(75 \%)$ of several C. indicum samples was phytochemically assessed by HPLC-DAD, and a diverse range of LN concentrations (2.08-55.68\%) was recorded [36]. Apart from a qualification study, in which the LN content was determined in the flower methanolic extract of C. indicum [32], hydro-ethanolic partition (95\%) of the flower and bud parts contained $48.3 \mathrm{mg} / \mathrm{g}$, whilst acetonitrile and water (in formic acid $0.1 \%$ ) in HPLC-DAD was used as the solvent system [30].

The flower hydro-ethanolic extract $(80 \%)$ was analyzed via HPLC-UV and LN was accordingly quantified $(32.8 \mathrm{mg} / \mathrm{g}$ ) [39]. The impacts of several extraction conditions on LN contents of the $C$. indicum flower ethanolic extract [40] have been explored; the highest LN yield $(88.11 \%)$ was measured in the plant samples extracted with $80 \%$ ethanol, $2 \mathrm{~h}$ of extraction, extraction frequency of three, and solvent to material ratio of $12 \mathrm{~mL} / \mathrm{g}$ [40].

HPLC-DAD-MS was formerly employed to analyze LN in the hydro-methanolic $(60 \%)$ extract of $C$. indicum [41]; in addition, a method for fingerprinting analysis of its methanolic extract via HPLC-DAD was introduced by Jung et al. (2012), where it contained $14.6-15.3 \mu \mathrm{g} / \mathrm{g}$ [42].

\subsubsection{Lamiaceae}

Lamiaceae, as the second richest LN natural source, has been analytically investigated by diverse groups. The occurrence of this flavone glycoside has been confirmed in various Mentha species. The flower methanolic fraction of M. arvensis was formerly analyzed and $6 \%$ of LN content was reported [46]. In a quantification measurement, the hydromethanolic (80\%) extract of aerial parts of $M$. arvensis was subjected to HPLC-DAD and UPLC-ESI/Q-TOF/MS, and the LN presence was validated [47].

This compound was further detected in the Menthahaplocalyx (Briq.) Trautm. extract (via HPLC-MS/MS) [76]; furthermore, Erenler et al. (2018) comparatively analyzed the ethyl acetate aerial part extracts of three other Mentha species including M. haplocalyx, Menthaspicata L., and Mentra x piperita L. The highest and lowest LN contents were observed in M. spicata and M. piperita samples with 42.21 and $0.04 \mathrm{mg} / \mathrm{g}$, respectively [48]. 
Marin et al. (2001), by using HPLC-UV, detected LN in the leaf hydro-methanolic (80\%) extracts of the following plant species: Acinos arvensis ssp. villosus, Acinos. Hungaricus (Simonk.) Šilic, Calamintha glandulosa (Req.) Benth., Micromeria albanica (K.Malý) Šilić, Micromeria cristata (Hampe) Griseb., Micromeria dalmatica Benth., Micromeria juliana (L.) Benth. ex Rchb., Micromeria thymifolia (Scop.) Fritsch, Satureja cuneifolia Ten., Satureja kitaibelii Wierzb. ex Heuff., and Satureja montana ssp. montana. Moreover, the leaf hydromethanolic fraction of Calamintha officinalis Moench was phytochemically analyzed through HPLC-UV and water-acetonitrile, and methanol as solvents, and LN with a concentration of $0.27 \mathrm{mg} / \mathrm{g}$ was identified [51].

The chemical composition of Ziziphora clinopodioides Lam. has further been studied analytically; UPLC-Q-TOF-MS was utilized to detect LN from its hydro-ethanolic (70\%) extract [77] as well as the quantification analysis of the herb methanolic fraction, where by applying RP-RRLC (RP-rapid resolution liquid chromatography), the LN contents were detected (3.15-20.55 mg/g) [53].

\subsubsection{Scrophulariaceae}

Buddleja spp. has been analytically elaborated in the case of its phytoconstituents; consequently, LN was detected as one of the main compounds. Fan et al. (2008) identified LN in the leaf methanolic fractions of Buddleja davidii Franch. and Buddleja nitida Benth., where LC-MS/MS was used. LN concentration of the ethanolic extracts (70\%) was assessed in the leaf and in vitro culture samples of Buddleja cordata Kunth including white and green callus and root samples by using HPLC-DAD, and the highest content was detected in the leaf ethanolic extract $(41.81 \pm 5.21 \mathrm{mg} / \mathrm{g})$ [56]. The hydro-ethanolic (70\%) fraction of Buddleja officinalis Maxim. flower was analyzed via utilization of UHPLC-LTQ-Orbitrap, and LN was consequently qualified [59]. The lyophilized infusion prepared from Linaria vulgaris Mill. has previously been experimented through HPLC-UV and LN was quantified with a significant content of $3.84 \mathrm{~g} / \mathrm{kg}$ drug [63].

\subsubsection{Valerianaceae}

Valeriana spp. has been characterized for its LN content. In [78], by applying HPLCDAD, they analytically investigated six Valeriana species (Valeriana edulis Nutt., Valeriana officinalis L., Valeriana jatamansi Jones, Valeriana procera Kunth, and Valeriana sitchensis Bong.), with the highest and lowest LN content detected in the methanolic extracts of $V$. jatamansi and $V$. edulis with 0.24 and $<0.002 \%$, respectively.

\subsubsection{Miscellaneous Plants}

The methanolic extracts of the Lobelia chinensis Lour. herb belonging to the Campanulaceae family were characterized for its phytochemicals by two analytical tools (LC-MS and HPLC-DAD-MS), and LN was qualified [66]. The hydro-ethanolic (70\%) fractions extracted from the inflorescence part of Coptis chinensis Franch. (Ranunculaceae family) were assessed via HPLC-MS and LN was identified as the main compounds [71]. Moreover, Rios et al. (2018) identified LN in the hexane, acetone, and methanolic extracts of Zanthoxylum affine Kunth (Rutaceae) aerial parts, whilst HPLC-Q-TOF-MS was employed with water and methanol as the solvent systems [72].

\section{Biological Properties of LN}

Generally, LN is still a relatively un-investigated drug resource. As a result, in this section, the therapeutic potential of LN and LN containing plants is summarized in Figure 2 and are classified according to which could be useful for potential clinical applications (Table S3). 


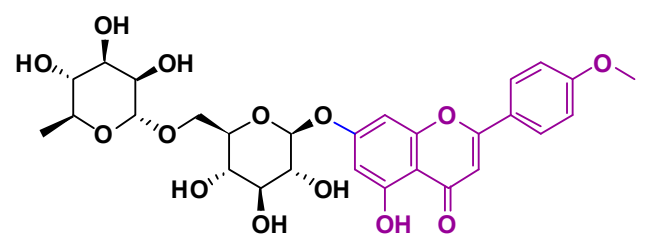

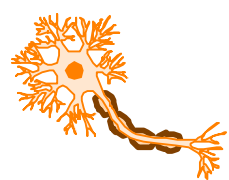

Anti-alzheimer

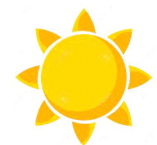

Photoprotection

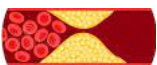

Ischemia protection

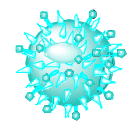

Anti-viral

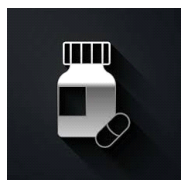

Sleep enhancing and sedative effect

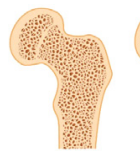

Anti-osteoporosis

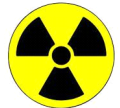

Radioprotection

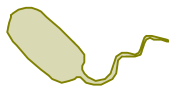

Anti-bacterial

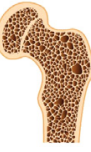

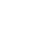
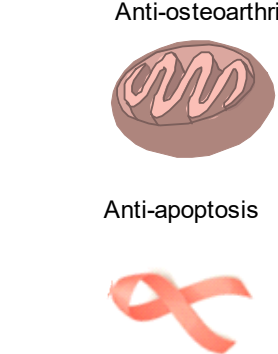

Anti-cancer and anti-proliferation

Anti-osteoarthritis

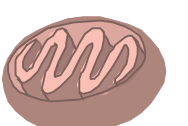

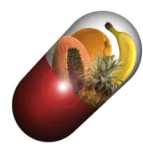

Antioxidant

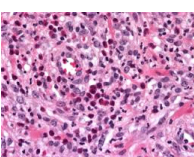

Anti-inflammation

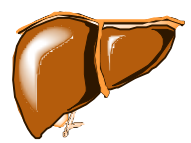

Hepatoprotection

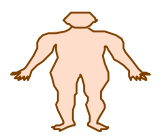

Anti-diabetic

Figure 2. Summary of the biological activities of LN.

\subsection{Anti-Alzheimer Properties}

One of the most successful strategies to target Alzheimer's disease is the development of agents that effectively interact with key enzymes involved in cholinergic dysfunction, especially acetylcholinesterase (AChE). This enzyme terminates the action of acetylcholine neurotransmitters and reduces the information transfer across the synapse [79]. Inhibitory potential of LN against AChE extracted from B. davidii was evaluated. Bioautographic assessment on LN and related flavonoids showed that the $4^{\prime}$-OMe group as well as the 7-substituted on the B-ring increased the inhibitory potency [54].

Feng et al. (2017) evaluated the AChE inhibitory potential of LN both in vitro and in vivo. In vitro assays using Ellman's colorimetric method exhibited an $\mathrm{IC}_{50}$ of $3.801 \pm 1.149 \mu \mathrm{M}$ [9]. A molecular docking study showed that the $4^{\prime}$-methoxyl group and the 7-O-sugar moiety of LN might be essential for AChE inhibition. Furthermore, ex-vivo study on mice showed that intraperitoneal administration of LN at doses of 35,70 , and $140 \mathrm{mg} / \mathrm{kg}$ decreased the AChE activity on the cortex and hippocampus of mice, where the inhibition effects of $\mathrm{LN}$ at the high dose were similar to huperzine $\mathrm{A}$ as the positive control $(0.5 \mathrm{mg} / \mathrm{kg})[80]$.

Pan et al. (2019) reported that $16.7 \mu \mathrm{g} / \mathrm{mL}$ and $50 \mu \mathrm{g} / \mathrm{mL}$ of $\mathrm{LN}$ (92\% pure) had prominent $\mathrm{AChE}$ inhibition in zebrafish [81]. In addition, this compound could significantly improve the recovery of dyskinesia in Alzheimer's disease (animal model). The hydroxyl groups of LN showed strong hydrogen bond interactions with residues Tyr130, Asn85, Trp84, and Asp72 at the anionic subsite of AChE; however, the methoxy flavone segment of LN exhibited $\pi-\pi$ interactions with residues Phe331, Trp279, and Phe290 of the peripheral anionic site [81]. The summary of the structure-activity relationship (SAR) of LN against AChE is presented in Figure 3. 


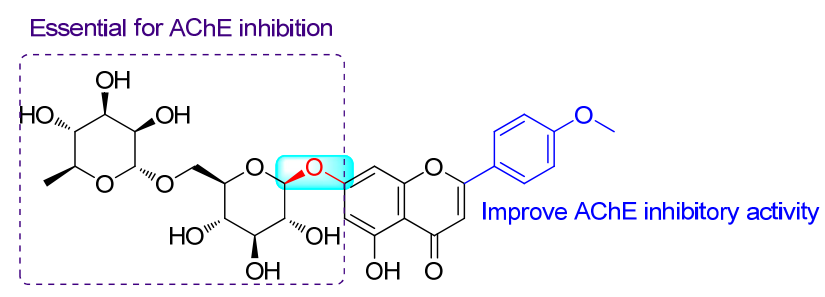

Figure 3. Structure-activity relationship of LN against AChE.

\subsection{Antioxidant Properties}

It is well-documented that oxidative stress and neurodegeneration are destructive in central nervous system (CNS) disorders such as Parkinson's disease and Alzheimer's disease, and protection of cells from oxidative stress toxicity might be beneficial in the abovementioned diseases. In this regard, Santos et al. exhibited the neuroprotective action of the V. officinalis extract in neuroblastoma SH-SY5Y of Parkinson's disease. To determine the mechanism of action, in silico molecular docking and molecular dynamics evaluations on apigenin, LN, hesperidin, and valerenic acid as the main compounds of Valeriana against hub gene transcripts were performed. Specifically, LN fitted strongly to sulfonylurea receptor-1 (SUR1). The ligand mainly interacted with SER 857, accepting one hydrogen bond and donating two. Most likely, LN can relieve the effects of oxidative stress during ATP depletion due to its ability to binding to SUR1 [82].

The high-performance liquid chromatography-electrospray ionization-mass spectrometry (HPLC-ESI-MS) analysis of C. japonicum exhibited chlorogenic acid, LN, and pectolinarin as the main compounds. Furthermore, the protective effect of $C$. japonicum on adrenal pheochromocytoma (PC12) cells in vitro and Caenorhabditis elegans (in vivo) were also assessed. The cell viability showed a steady increase until $50 \mu \mathrm{g} / \mathrm{mL}$ and then decreased. Pre-treatment of extracts in PC12 cells significantly prevented intracellular ROS accumulation in comparison to the $\mathrm{H}_{2} \mathrm{O}_{2}$ treated control $(p<0.05)$. Under normal growth conditions, treatment with 50 and $100 \mu \mathrm{g} / \mathrm{mL}$ C. japonicum extract for $96 \mathrm{~h}$ greatly reduced intracellular ROS levels by $37 \%$ and 39\%, respectively, compared to the control [83].

In the other study, the neuroprotective effect of $\mathrm{LN}$ against $\mathrm{H}_{2} \mathrm{O}_{2}$-induced oxidative stress in rat hippocampal neurons was assessed. The results showed that $\mathrm{H}_{2} \mathrm{O}_{2}$ at $400 \mu \mathrm{M}$ markedly increased the number of apoptotic neurons, while treatment of the neurons with LN significantly reduced the cell death induced by $\mathrm{H}_{2} \mathrm{O}_{2}$ [84].

\subsection{Sleep Enhancing and Sedative Effect}

A set of flavonoid glycosides was evaluated for the sedative, sleeping, and locomotor activity. The following potencies were consequently reported $2 \mathrm{~S}$-hesperidin $>\mathrm{LN}>$ rutin $>$ diosmin \cong 2S-neohesperidin > gossypin $\sim$ 2S-naringin. The SAR proposed the important role of the $1 \rightarrow 6$ bond between rhamnose and glucose while changing the bond to $1 \rightarrow 2$, a remarkable decrease in the activity [85].

Nugroho et al. (2013) reported that LN isolated from the C. boreale methanolic extract possessed sedative and sleep-enhancing properties [86]. In detail, 10 and $20 \mathrm{mg} / \mathrm{kg} \mathrm{LN}$ reduced the latency time for the loss of righting reflex caused by pentobarbital injection and delayed the total duration of sleeping time to around $100 \mathrm{~min}$ in mice [86].

\subsection{Anti-Osteoporosis Activity}

The potential application of LN (isolated from B. officinalis) in the response against oxidative stress on osteoblastic MC3T3-E1 cells exposed to $\mathrm{H}_{2} \mathrm{O}_{2}$ was evaluated. LN $(0.2 \mu \mathrm{g} / \mathrm{mL})$ significantly increased cell survival, alkaline phosphatase (ALP) activity, collagen content, calcium deposition, and osteocalcin secretion, whereas it decreased the production of the receptor activator of nuclear factor-kB ligand (RANKL), protein carbonyl (PCO), and malondialdehyde (MDA) of osteoblastic MC3T3-E1 cells in the presence of hydrogen peroxide. It was shown that LN exerts antiresorptive actions through the reduction of RANKL and oxidative damage [58]. With more focus toward the antioxidant potential 
of LN, in another study, the antiosteoporosis activity of Flos Chrysanthemi indici on bone loss in ovariectomized mice was evaluated. All isolated compounds including acacetin, apigenin, luteolin, and LN enhanced the differentiation and proliferation of osteoblasts in MC3T3-E1 cells. They also improved the mRNA levels of runt-related transcription factor 2 (RUNX2), osteocalcin (OCN), osteopontin (OPN), and type I collagen. The AKT signaling pathway was also activated in MC3T3-E1 cells by the four compounds [39].

Li et al. (2016) comprehensively evaluated the molecular mechanism pathway of LN on osteoblast differentiation. First, extracted LN from Flos Chrysanthemi indici was assessed on MC3T3-E1 cells (a mouse osteoblastic cell line), and next, the osteoprotective effect of LN in mice was evaluated. LN upregulated osteogenesis-related gene expression including that of ALP, OCN, RUNX2, bone sialoprotein (BSP), and type I collagen. Additionally, it was shown that LN enhanced osteoblast proliferation and differentiation in MC3T3-E1 cells dose-dependently through enhanced ALP activity and mineralization of the extracellular matrix by activating the BMP-2/RUNX2 pathway through protein kinase A signaling in vitro, promoting osteoid gene expression and protecting against OVX-induced bone loss in vivo [87].

In addition, a reducing impact of LN on the RANKL-induced macrophage differentiation into multinucleated osteoclasts and osteoclastic bone resorption through reducing lacunar acidification and bone matrix degradation has been demonstrated. Moreover, LN reduced the transmigration and focal contact of osteoclasts to bone matrix-mimicking RGD peptide, which was accomplished by inhibiting the induction of integrins, integrinassociated proteins of paxillin, and gelsolin, cdc42, and CD44 involved in the formation of actin rings [88].

\subsection{Osteoarthritis Treatment}

Osteoarthritis is an age-related joint disease characterized by the degeneration of articular cartilage and chronic pain. Recent studies have confirmed the potential role of antiinflammatory agents to target osteoarthritis. The LN treatment suppressed lipopolysaccharide (LPS), causing the overproduction of nitric oxide (NO), prostaglandin E2 (PGE2), IL-6, and TNF- $\alpha$ in chondrocyte. In addition, the LPS-stimulated expression of cyclooxygenase-2 (COX-2) and inducible nitric oxide nitrate (iNOS) was decreased by LN pre-treatment. The mechanism of action showed the suppression of Toll-like receptor 4 (TLR4)/myeloid differentiation protein-2 (MD-2) dipolymer complex formation and subsequently intervened in nuclear factor kappa-B (NF-kB) activation [89].

The osteoarthritis mechanism of action of $C$. zawadskii var. latilobum extract revealed that the matrix metalloproteinases-1 (MMP-1), MMP-3, MMP-9 and MMP-13 expressions were inhibited by the dose-dependent extract, while expressions of the ECM synthetic genes, COL2A1 and ACAN, and the transcription factor SOX9 were increased to normal condition by the extract treatment dose-dependently. It would be interesting to note that SOX9 is a repressor of ECM-degrading aggrecanases, disintegrin, and metalloproteinase with thrombospondin motifs-4 (ADAMTS-4) and ADAMTS-5, and this extract considerably reduced the levels of these enzymes; it is worth mentioning that these potencies can remarkably be correlated to the LN content of the extract possessing $22.8 \mathrm{mg} / \mathrm{g}$ [75].

\subsection{Ischemia Protection}

In the other study, the effect of LN to inhibit ischemia-reperfusion injury was also evaluated. The primary study confirmed the low toxicity of $\mathrm{LN}(\leq 30 \mu \mathrm{M})$ against normal H9C2 cells. Further assessments showed that LN could protect myocardial tissue from the injury of ischemia-reperfusion related to activation of the Nrf-2 and PI3 K/Akt signaling pathway. Meanwhile, the antioxidative enzymes, regulated by Nrf-2, were enhanced against the oxidative stress caused by hypoxia-reoxygenation. Importantly, with the inhibition of oxidative stress, some proliferation and apoptosis-related proteins such as NF-кB and cytochrome $C$ were adjusted to support the viability of cells [90]. 
Furthermore, the anti-inflammatory effect of LN during ischemia-reperfusion-acute kidney injuries was assessed. LN inhibited the acute kidney injury in an in vivo ischemiareperfusion injury model and decreased the expression of interleukin-12 (IL-12) p40 in in vivo and in vitro models. Evaluation on the mechanism of action of LN identified E26 oncogene homolog 2 (ETS2) protein transcription factor for its regulatory action on IL-12 p40 according to microarray analysis and protein-protein interaction. In addition, in silico study showed that the contact area ETS2 is highly conserved and located on a PPI domain of ETS2, which designates that LN may alter the interaction with synergistic proteins in the regulation of IL-12 p40 expression [91].

\subsection{Anti-Inflammation Activity}

Anti-inflammatory assessment of forty-two identified compounds from Chrysanthemi indici showed that LN, 3,5-dicaffeoylquinic acid, and luteolin with good biocompatibility could be considered as the important contributors to the anti-inflammatory effect of this plant, which decreased levels of NO, TNF- $\alpha$, IL-6, and PGE2 in RAW264.7 macrophage cells treated with LPS [92].

In another study, the pelvic inflammatory disease with dampness-heat stasis syndrome was investigated and showed that LN at 8-32 $\mu \mathrm{M}$ can significantly inhibit the NO release in a concentration-dependent manner. Results also confirmed that the inhibitory effects on NO production were not due to the cytotoxicity but strong inhibition of NO production. However, the rapid response of LN on the release of TNF- $\alpha$ upon LPS stimulation for $2 \mathrm{~h}$ was not significant [93].

\subsection{Photoprotective Properties}

Acevedo et al. (2005) studied the photoprotective properties of the methanolic extract of Buddleja scordioides as well as verbascoside, LN, and linarin peracetate against UV-B induced cell death using E. coli as a cell model. Linarin peracetate $(2 \mathrm{mg} / \mathrm{mL})$ protected bacteria efficiently with cell death after 125-250 min, while LN reached cell death until 40-80 min. Interestingly, the sun protection factor (SPF) in guinea pigs was $9 \pm 0.3$ in the $\mathrm{LN}\left(2 \mathrm{mg} / \mathrm{cm}^{2}\right)$ receiving group, while linarin acetate showed a SPF of $5 \pm 0.2$. The methanolic extract had the smallest SPF $(3 \pm 0.09)$, probably due to the low concentration of the photoprotective compound [61].

Examination of the photoprotective properties of Buddleja cordata against UVB-induced skin damage in SKH-1 hairless mice showed that $200 \mu \mathrm{L}$ of $2 \mathrm{mg} / \mathrm{mL}$ extract successfully reduced the redness of UVB irradiation to around 120 within $24 \mathrm{~h}$ of UV exposure compared to the untreated group with a redness of 300 [94].

\subsection{Radioprotection}

In another study, LN isolated from Chrysanthemum morifolium flowers significantly decreased the IR-induced cell migration and invasion at a concentration of $5 \mu \mathrm{M}$ in A549 (human lung cancer cells). LN affected cell viability with an $\mathrm{IC}_{50}$ value of $282 \mu \mathrm{M}$. The mechanism was confirmed via inhibiting NF- $\kappa$ B and I $\kappa$ B $-\alpha$ phosphorylation as well as MMP-9 downregulation [95].

\subsection{Anti-Apoptosis Potential}

The liver injury and hepatic fibrosis caused by the co-treatment with D-galactosamine $(\mathrm{GalN}) /$ lipopolysaccharide (LPS) have been extensively approved. Apoptosis is an important cellular pathological process in GalN/LPS-induced liver injury.

In a study conducted by JooKim et al., the cytoprotective mechanisms of LN against GalN/LPS-induced hepatic failure in mice were evaluated. After $6 \mathrm{~h}$ of GalN/LPS injection, the serum levels of alanine aminotransferase, aspartate aminotransferase, TNF- $\alpha$, IL-6, and interferon- $\gamma$ as well as TLR4 and interleukin-1 receptor-associated kinase (IRAK) expression were significantly elevated. 
LN $(50 \mathrm{mg} / \mathrm{kg}$ ) treatment reversed the lethality induced by GalN/LPS via decreasing the levels of TLR4, IRAK, and suppressing the serum release and hepatic mRNA expression of TNF- $\alpha$, IL-6, and IFN- $\gamma$. In the TUNEL assay, in which the apoptotic cells were monitored, LN also suppressed the increase in the number of apoptotic cells and reduced the cytosolic release of cytochrome $\mathrm{c}$ and caspase-3 cleavage.

LN administration increased the level of anti-apoptotic Bcl-xL and ratio of p-STAT3/ STAT3 protein. Furthermore, LN attenuated the expression of FAS-associated death domain and caspase-8, and reduced the pro-apoptotic Bim phosphorylation induced by GalN/LPS.

These results confirmed the potential properties of LN to suppress TNF- $\alpha$-mediated apoptotic pathways and pro-apoptotic Bim phosphorylation as well as enhance STAT3 activity and increase anti-apoptotic Bcl-xL levels [33].

\subsection{Hepatoprotective Function}

HPLC-MS analysis of the Coptis chinensis inflorescence extract detected 18 flavonoids and alkaloids derivatives including magnoflorine, thebaine, anonarine $5-\mathrm{OH}$ berberine, jateorhizine, columbamine, coptisine, epiberberine, palmatine, berberine, worenine, and LN. Cell viability assessment of Coptis chinensis inflorescence extract and LN in HepG2 cells exhibited IC $_{50}$ values of 291.15 and $83.88 \mu \mathrm{g} / \mathrm{mL}$, respectively. Next, the hepatoprotective function of $C$. chinensis and $\mathrm{LN}$ showed the reduction in reactive oxygen species (ROS) generation induced by $\mathrm{CCl}_{4}$ in $\mathrm{HepG} 2$ cells. $\mathrm{LN}$ could also phosphorylate mitogenactivated protein kinases (MAPKs) and upregulate Kelth-like ECH-associated protein (Keap1). The pathways of MAPKs and Keap1 lead to the separation of Keap1 and nuclear factor (erythroid-derived 2)-like 2 (Nrf2). Note that the free Nrf2 transferred to the nucleus and enhanced the expression of phase II detoxification enzymes [71].

\subsection{Non-Alcoholic Steatohepatitis Effect}

Nonalcoholic steatohepatitis (NASH), known as liver inflammation and damage caused by a buildup of fat in the liver, is recognized as a common cause of elevated liver enzymes [96]. Investigations of high-fat high-cholesterol diet in rats showed that LN could suppress the expression of mRNA levels of hepatic inflammation cytokines including monocyte chemotactic protein and TNF- $\alpha$ as well as chemokine ligand 1 (CXCL1). A high dose of LN-extract $(60 \mathrm{mg} / \mathrm{kg})$ significantly lowered the serum alanine aminotransferase (ALT) and aspartate aminotransferase (AST) and inhibited the activation of the c-Jun $\mathrm{N}$-terminal kinase (JNK) induced by a high-fat high-cholesterol diet [97].

\subsection{Anti-Diabetic Effects}

The anti-diabetic effects of the Chrysanthemum zawadskii extract at different doses (125, 250 , and $500 \mathrm{mg} / \mathrm{kg}$ body weight) were investigated every day for five or six weeks. The extraction was standardized and showed $1.32 \pm 0.22 \mathrm{mg} \mathrm{LN} / \mathrm{g}$ extract. Subsequently, the extract significantly decreased fasting blood glucose levels in streptozotocin and streptozotocin and high fat diet-induced diabetic models, even at low doses. In addition, glucose tolerance and insulin tolerance were improved by increasing insulin levels and decreasing hemoglobin A1c (HbA1c) levels in serum [98].

Yang-Ji et al. (2016) also demonstrated that the Chrysanthemum zawadskii extract could effectively inhibit the lipase and $\alpha$-glucosidase enzymes to target the diabetic. This potency might well be correlated with the LN content [99].

Similarly, molecular docking, molecular dynamic, conceptual DFT, and pharmacophore mapping studies against $\alpha$-amylase and $\alpha$-glucosidase illustrated that LN could be a beneficial preventative and possibly therapeutic agent against diabetes [100].

\subsection{Analgesic and Anti-Pyretic Properties}

MartInez-Vázquez et al. (1996) evaluated the potential analgesic and antipyretic activities of aqueous extract of leaves of Buddleia cordata as well as its main compound LN in animal models [101]. The oral administration of an aqueous extract of $B$. cordata and 
LN showed a dose-dependent antipyretic activity. Aqueous extract and LN (100 mg/kg) remarkably increased the reaction time of mice by $70 \%$ and $55 \%$ on heat-induced pain, respectively. Similarly, the antipyretic effect of LN was better than that of the aqueous extract in the yeast-induced hyperthermia test. Three hours after the treatment, LN displayed maximal inhibitory effect with the average temperature being reduced by $1.8^{\circ} \mathrm{C}$ $(50 \mathrm{mg} / \mathrm{kg})$ and $2.0^{\circ} \mathrm{C}(100 \mathrm{mg} / \mathrm{kg})$, whilst the extract reduced hyperthermia by 1.4 and $1.9^{\circ} \mathrm{C}$ at 100 and $200 \mathrm{mg} / \mathrm{kg}$, respectively [101].

\subsection{Spasmolytic Properties}

So far, many studies have approved the remarkable antispasmodic effects of the flavonoids presented in diverse plant species [102-104]. LN also showed an acceptable effect investigated by one study. Phytochemical investigation of the hydro-ethanolic extract of $L$. japonicus resulted in the extraction of three flavonoid glycosides named spinosin, LN, and apigenin-7-O- $\beta$-D-glucopyranoside as well as four cyclopeptides and nine alkaloids. These compounds were used in the uterine contraction assay. The findings demonstrated that the flavonoid glycosides (spinosin, LN, and apigenin-7-O- $\beta$-D-glucopyranoside) at $50 \mu \mathrm{M}$ inhibited the contraction of the uterine smooth muscle strips significantly; viscerally, cyclopeptides and alkaloids increased contraction of uterine smooth muscle [50].

\subsection{Treatment of Chronic Venous Hypertension}

In a previous experiment, $100 \mathrm{mg} / \mathrm{kg} /$ day MPFF (diosmetin, hesperidin, LN, and isorhoifolin) in a chronic venous hypertension animal model showed significant prevention of capillary rarefaction and inflammatory cascade by decreasing the number of sticking leukocytes. MPFF reduced the enlargement of venular diameter as well as maintained venous tone [105].

\subsection{Anti-Bacterial Activity}

Corn mint (Mentha arvensis) provides a good source of LN and rosmarinic acid. The methanolic extract inhibited the growth of Chlamydia pneumoniae CWL-029 in vitro in a dose-dependent manner. The antichlamydial effect of LN showed complete growth inhibition of strain bacterium Chlamydia pneumoniae, and inhibited the growth of strain K7 by $>60 \%$ at $100 \mu \mathrm{M}$. Administration of M. arvensis extract ( $20 \mathrm{mg} / \mathrm{kg}, 3$ days) was able to significantly diminish the inflammatory parameters related to $C$. pneumoniae infection in mice $(p=0.019)$ [47].

\subsection{Anti-Viral Activity}

Virus is a threat to public health due to its high mutation rate and resistance to existing drugs. Recently, the antiviral activity of LN was investigated to develop new antiviral agents. Evaluation of the flavonoid prescription drug baicalin-linarin-icariinnotoginsenoside R1 was assessed on duck virus hepatitis (DVH) caused by duck hepatitis A virus type 1 (DHAV-1). The mentioned drug showed an anti-DHAV-1 ability with T and B lymphocytepromoting effects. It also inhibited DHAV-1 reproduction by suppressing its adsorption and release. The mechanism of this antiviral effect showed that the drug at $5 \mu \mathrm{g} / \mathrm{mL}$ increased $\mathrm{T}$ and $\mathrm{B}$ lymphocyte proliferation. Moreover, according to the in vivo study, the drug stimulated total anti-DHAV-1 antibody secretion in ducklings at the dosage of $4 \mathrm{mg}$ per duckling, but had no significant stimulation impact on the IL-2 and IFN-c secretion [106].

In another study, Chen et al. (2017) assessed the baicalin-LN-icariin-notoginsenoside R1 on DHAV-1 as well as its hepatoprotective and antioxidative potencies. Results showed that the DHAV-1 inhibitory rate of this multi-therapy was $69.3 \%$ at $20 \mu \mathrm{g} / \mathrm{mL}$. The survival rate of ducklings treated by $3 \mathrm{mg}$ drug per duckling (once a day for five days) was about $35.5 \%$, which was significantly higher than that of the virus control $(0.0 \%)$. Additionally, the degree of oxidative stress, the serum MDA, SOD, CAT, and GSH-Px levels at 8 and $54 \mathrm{~h}$ were measured and demonstrated a significant reduction compared to the blank and virus groups, which showed the reduction of oxidative stress in the infected duck [107]. 
Human immunodeficiency virus (HIV) is an infection that attacks the body's immune system, specifically the white blood cells called CD4. The development of anti-HIV-1 drugs has gained much attention nowadays [108]. It has been shown that human $\gamma \delta \mathrm{T}$ cells (lymphocytes) consist of V81-TCR-expressing V $81+\mathrm{T}$ cells and V82-TCR-expressing V $82+$ $\mathrm{T}$ cells, which play pivotal roles in bridging innate and adaptive immunity. It was proposed that stimulation V $\delta 1+T$ cells may constitute a new class of anti-HIV drugs, targeting the mucosal compartment to suppress the R5-type of HIV-1. Yonekawa et al. (2019) reported that $\mathrm{LN}$ at $100 \mu \mathrm{g} / \mathrm{mL}$ and some flavonoid glycosides, which have both rutinose at the $\mathrm{A}$ ring and methoxy substitution at the B ring, can activate host V $\delta 1+\mathrm{T}$ cells in HIV patients and can contribute to limiting the R5-type of HIV-1 replication. LN stimulated PBMCderived V $\delta 1+\mathrm{T}$ cells to secrete chemokines MIP- $1 \alpha$, MIP- $1 \beta$, and RANTES and cytokines such as IL-5 and IL-13, which may improve the immune system [109]. Figure 4 exhibits the structure-activity relationship of LN against HIV.

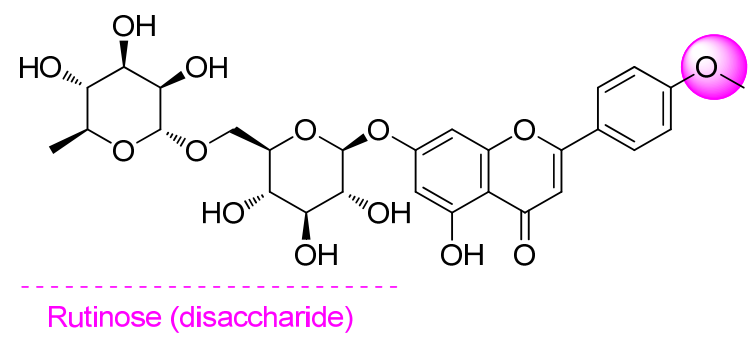

Figure 4. Structure-activity relationship of LN against HIV.

In another study, virtual screening on Chinese medicinal compounds was applied to discover novel natural drugs against the influenza A virus using Naïve Bayesian classifiers, and mt-QSAR models. In the selected set, LN exhibited a significant reduction in TNF- $\alpha$ expression to around $40 \mathrm{pg} / \mathrm{mL}$ compared to the control group with $\sim 80 \mathrm{pg} / \mathrm{mL}$, whereas it may regulate the expression of cytokines and chemokines, which represent direct and indirect suppression of influenza A [110].

\subsection{Anti-Cancer and Anti-Proliferative Activity}

Cancer is one of the major causes of death worldwide, affecting more than 14.1 million people worldwide [111]. Over the past few years, attention has been paid to find potent natural products as anticancer therapeutic agents [79,112,113].

Flavonoids are known to be one of the most popular groups of bioactive phytochemicals with anticancer activity; however, limited study has been conducted to evaluate the activity of LN as anticancer agents [79].

The methanolic extract of Chrysanthemum indicum and purified LN exerted antiproliferative activity against human non-small cell lung cancer cells via suppression of Akt activation and induction of cyclin-dependent kinase inhibitor p27Kip1, as evidenced by cell cycle analysis and treatment with LY294002. These findings may indicate the anticancer potential of LN as the core functional constituent of C. indicum [114].

Glioma is the most common form of malignant brain cancer with a high mortality rate in humans. NF- $\mathrm{kB}$ activity is a common phenomenon in various cancers, resulting in abnormal cell proliferation, malignant transformation, or resistance to cell death. Previously, the anti-cancer role of LN in glioma was tested in vitro and in vivo. LN suppressed glioma cell proliferation and migration by inducing apoptosis, which was through reducing the cell cycle-related signals including survivin, $\mathrm{p}-\mathrm{Rb}$, and cyclin $\mathrm{D} 1$, while promoting $\mathrm{p} 21$, Bax, caspase-3, and poly (ADP-ribose) polymerase (PARP) activation. LN also showed an increase in $\mathrm{P} 53$ as an essential tumor suppressor. Moreover, it reduced cellular proliferation of glioma through p53 upregulation and NF- $\mathrm{kB} / \mathrm{p} 65$-downregulation, thereby inhibiting glioma cell growth [115].

The cytotoxicity of Jatropha pelargoniifolia loaded chitosan nanoparticles against A549 human lung adenocarcinoma cells $\left(\mathrm{IC}_{50}=13.17 \mu \mathrm{M}\right)$ was higher than that of the free extract 
$\left(\mathrm{IC}_{50}=25.16 \mu \mathrm{M}\right)$ and comparable to that of methotrexate $\left(\mathrm{IC}_{50}=11.84 \mu \mathrm{M}\right)$ as an anticancer drug [116].

Oral squamous cell carcinoma is characterized by overexpression of Akt1 (RACalpha serine/threonine-protein kinase) and Akt2 (RAC-beta serine/threonine-protein kinase). It was reported that Akt1 and Akt2 inhibitors can lead to oral squamous cell carcinoma treatment with no affinity toward monoamine oxidase B (MAOB). In silico studies introduced LN as inhibitors of Akt1 and Akt2 with strong binding affinities of $11.5 \mathrm{kcal} / \mathrm{mol}$ and $11.1 \mathrm{kcal} / \mathrm{mol}$, respectively, with no affinity toward MAOB, which can be an ideal candidate for oral squamous cell carcinoma treatment [117].

\subsection{Negative Biological Results of $L N$ \\ 3.20.1. Estrogenic Activity}

The estrogenic activity of six chemical constituents (apigenin, hispidulin, cirsimaritin, cirsimarin, pectolinarin, and LN) isolated from Cirsium japonicum on MCF-7 cells was assessed. Among them, hispidulin and cirsimaritin showed strong estrogen receptor transactivation, while the rest of the compounds had weaker or relatively no effects. The SAR confirmed that estrogen receptor transactivation increases as the number of $-\mathrm{OH}$ groups in the flavonoid structure increased [19].

\subsubsection{Anti-Fungal Effect}

Combined chromatographic techniques were implemented in the phytochemical analysis of Lippia rubella, leading to the isolation of several compounds such as lippiarubelloside A and lippiarubelloside B, verbascoside as well as LN. Inhibitory evaluation of LN against some fungal strains such as Candida albicans (ATCC 10231) and Candida parasilopsis (ATCC 22019) asserted no significant activity (MIC $>125 \mu \mathrm{g} / \mathrm{mL}$ ), and moderate effects against Cryptococcus neoformans and Cryptococcus neoformans (MIC: $125 \mu \mathrm{g} / \mathrm{mL}$ ) [73].

\subsubsection{Anti-Depressant Properties}

Depression is a mental health disorder characterized by loss of interest, pleasure, with feelings of sadness, low self-worth, and tiredness, which disturbed sleep or appetite, leading to suicide in severe cases. The exact mechanism of depression is still unknown, and most of the antidepressants act as inhibitors of intracellular monoamine (exp, norepinephrine) reuptake. Additionally, it has been shown the gamma-aminobutyric acid (GABA) levels as well as cortical GABAA receptors decreased in patients with depression.

In this regard, the norepinephrine reuptake of Cirsium japonicum and its major constituents (linarin, pectolinarin, chlorogenic acid, luteolin) were evaluated. Cirsium japonicum showed an antidepressant effect by significantly reducing the immobile behavior of mice in the forced swimming test, without enhancing locomotor activity in the open-field test. In addition, the $C$. japonicum extract had no effect on monoamine uptake while significantly promoting $\mathrm{Cl}^{-}$ion influx in human neuroblastoma cells and modulating the GABAA receptor. Further evaluation showed that among the major constituents of the C. japonicum extract, only luteolin produced antidepressant activity as a positive modulator of the GABA-mediated $\mathrm{Cl}^{-}$ion channel complex and $\mathrm{LN}$ was almost inactive [118]. Results showed that the antidepressant effect of Cirsium japonicum could be due to the luteolin constituent.

\section{Perspectives}

\section{Anti-SARS-CoV-2 (COVID-19) Effect}

Severe acute respiratory syndrome-coronavirus 2 (SARS-CoV-2) is a RNA airborne virus infection known as the pathogen responsible for coronavirus disease 2019 (COVID-19) [119]. Millions of COVID-19 patients have been reported thus far; however, there is no concrete evidence on the effectiveness and safety of the specific treatment against SARS-CoV-2 [120,121]. One area that has been affected immensely is the investigation of natural remedies as medications and/or supportive therapies to treat patients with 
COVID-19 infection. Mostly, antiviral drugs directly target the infecting pathogen to halt its development [122]. In the case of SARS-CoV-2, the influence of active substances of medicinal plants were surveyed in inhibiting four important druggable targets including $S$ and $\mathrm{N}$ proteins, 3CLpro, and RdRp. RdRp controls the replication of SARS-CoV-2 while $3 C$ pro is the main protease of the virus. Moreover, $\mathrm{N}$ and $\mathrm{S}$ proteins are responsible for SARS-CoV-2 assembly and attachment, respectively. Molecular docking outcomes of the study revealed that LN, amentoflavone, (-)-catechin gallate, and hypericin had an affinity for these basic proteins, which possess an effective role in SARS-CoV-2 infection [123].

\section{Conclusions}

Investigation of plant secondary metabolites with valuable impacts on human health is an attractive and broad research area. Flavonoids, a large family of phenolic compounds due to their pivotal therapeutic effects, have been the subject of many studies. Nowadays, their diverse derivatives are widely consumed as dietary supplements. Although the most renowned flavonoids (i.e., apigenin, luteolin, hispidulin, kaempferol, myricetin, quercetin, naringenin, etc.) are aglycosylated [124], the glycosylated forms are also of interest. It is believed that the glycosylation of flavonoids can lead to the development of their biological features by reducing the probable toxicity and increasing their bioavailability [125].

The present context overviewed a very promising but not well-investigated glycosylated flavone named LN. From the phytochemical viewpoint, the plant genus Cirsium, Micromeria, Buddleja, and Chrysanthemum are the major natural sources of LN. This compound demonstrated promising bioactivities through the studies carried out in vitro and in vivo. The encouraging properties of LN have been shown through osteoblast proliferation and differentiation with high anti-arthritis and antiosteoporosis potencies; however, its effect on the treatment of CNS disorders have also been pointed out.

Further phytochemical investigations of different natural sources leading to the isolation and identification of $\mathrm{LN}$ as well as exploring the optimized extraction methods can support the implementation of its bioactivity assessments. Complementary biological and pharmacological evaluations (particularly toxicity and clinical trials) of LN and its derivatives are proposed in future in order to develop potential natural-based drugs/supplements with the least side effects.

Supplementary Materials: The followings are available online at https:/ / www.mdpi.com/article/ 10.3390/ph14111104/s1, Table S1: Isolation and identification of linarin from plant species; Table S2: Identification and characterization of linarin from plant species; Table S3: Biological properties of linarin. References [126-138] are cited in the supplementary materials.

Author Contributions: Conceptualization, methodology, writing, and supervision by J.M.; Data collection by H.T., A.B.D. and M.M.S.; Investigation and writing by K.Z., C.I. and A.I. were performed. All authors have read and agreed to the published version of the manuscript.

Funding: This research received no external funding.

Institutional Review Board Statement: Not applicable.

Informed Consent Statement: Not applicable.

Data Availability Statement: Not applicable.

Acknowledgments: The authors wish to thank the support of the Vice-Chancellor for Research of Shiraz University of Medical Sciences (Grant No. 24425). This agency was not involved in the design of the study and collection, analysis, and interpretation of data as well as in writing the manuscript.

Conflicts of Interest: The authors declare no conflict of interest.

\section{References}

1. Mottaghipisheh, J.; Kiss, T.; Tóth, B.; Csupor, D. The Prangos genus: A comprehensive review on traditional use, phytochemistry, and pharmacological activities. Phytochem. Rev. 2020, 19, 1449-1470. [CrossRef] 
2. Mottaghipisheh, J.; Maghsoudlou, M.T.; Valizadeh, J.; Arjomandi, R. Antioxidant activity and chemical composition of the essential oil of Ducrosia anethifolia (DC.) Boiss. from Neyriz. J. Med. Plants By-Prod. 2014, 2, 215-218.

3. Dehsheikh, A.B.; Sourestani, M.M.; Dehsheikh, P.B.; Mottaghipisheh, J.; Vitalini, S.; Iriti, M. Monoterpenes: Essential oil components with valuable features. Mini-Rev. Med. Chem. 2020, 20, 958-974. [CrossRef] [PubMed]

4. Bhattacharya, A. High-temperature stress and metabolism of secondary metabolites in plants. In Effect of High Temperature on Crop Productivity and Metabolism of Macro Molecules; Elsevier: London, UK, 2019; pp. 391-484.

5. Kwok, K.K.; Vincent, E.C.; Gibson, J.N. Antineoplastic drugs. In Pharmacology and Therapeutics for Dentistry; Elsevier: Amsterdam, The Netherlands, 2017; pp. 530-562.

6. Pullaiah, T.; Raveendran, V. Camptothecin: Chemistry, biosynthesis, analogs, and chemical synthesis. In Camptothecin and Camptothecin Producing Plants; Elsevier: Amsterdam, The Netherlands, 2020; pp. 47-101.

7. Dockery, L.; Daniel, M.-C. Dendronized Systems for the Delivery of Chemotherapeutics. Adv. Cancer Res. 2018, 139, 85-120. [PubMed]

8. Panche, A.N.; Diwan, A.D.; Chandra, S.R. Flavonoids: An overview. J. Nutr. Sci. 2016, 5, e47. [CrossRef]

9. Feng, W.; Hao, Z.; Li, M. Isolation and structure identification of flavonoids. In Flavonoids_From Biosynthesis to Human Health; InTech: Rijeka, Croatia, 2017; pp. 17-23.

10. Yamagata, K. Metabolic syndrome: Preventive effects of dietary flavonoids. Stud. Nat. Prod. Chem. 2019, 60, 1-28.

11. Mottaghipisheh, J.; Stuppner, H. A comprehensive review on chemotaxonomic and phytochemical aspects of homoisoflavonoids, as rare flavonoid derivatives. Int. J. Mol. Sci. 2021, 22, 2735. [CrossRef]

12. Mottaghipisheh, J.; Iriti, M. Sephade ${ }^{\circledR}$ LH-20, isolation, and purification of flavonoids from plant species: A comprehensive review. Molecules 2020, 25, 4146. [CrossRef]

13. Arai, M.A.; Tanaka, M.; Tanouchi, K.; Ishikawa, N.; Ahmed, F.; Sadhu, S.K.; Ishibashi, M. Hes1-binding compounds isolated by Target Protein Oriented Natural Products Isolation (TPO-NAPI). J. Nat. Prod. 2017, 80, 538-543. [CrossRef]

14. Demirtas, I.; Tufekci, A.R.; Yaglioglu, A.S.; Elmastas, M. Studies on the antioxidant and antiproliferative potentials of Cirsium arvense subsp. vestitum. J. Food Biochem. 2017, 41, e12299. [CrossRef]

15. Kozyra, M.; Biernasiuk, A.; Malm, A.; Chowaniec, M. Chemical compositions and antibacterial activity of extracts obtained from the inflorescences of Cirsium canum (L.) all. Nat. Prod. Res. 2015, 29, 2059-2063. [CrossRef] [PubMed]

16. Ganzera, M.; Pöcher, A.; Stuppner, H. Differentiation of Cirsium japonicum and C. setosum by TLC and HPLC-MS. Phytochem. Anal. 2005, 16, 205-209. [CrossRef] [PubMed]

17. Ma, Q.; Jiang, J.-G.; Zhang, X.-M.; Zhu, W. Identification of luteolin 7-O- $\beta$-D-glucuronide from Cirsium japonicum and its anti-inflammatory mechanism. J. Funct. Foods 2018, 46, 521-528. [CrossRef]

18. Zhang, Z.; Jia, P.; Zhang, X.; Zhang, Q.; Yang, H.; Shi, H.; Zhang, L. LC-MS/MS determination and pharmacokinetic study of seven flavonoids in rat plasma after oral administration of Cirsium japonicum DC. extract. J. Ethnopharmacol. 2014, $158,66-75$. [CrossRef] [PubMed]

19. Lee, D.; Jung, Y.; Baek, J.Y.; Shin, M.S.; Lee, S.; Hahm, D.H.; Lee, S.C.; Shim, J.S.; Kim, S.N.; Kang, K.S. Cirsimaritin contributes to the estrogenic activity of Cirsium japonicum var. maackii through the activation of estrogen receptor $\alpha$. Bull. Korean Chem. Soc. 2017, 38, 1486-1490. [CrossRef]

20. Han, H.-S.; Shin, J.-S.; Lee, S.-B.; Park, J.C.; Lee, K.-T. Cirsimarin, a flavone glucoside from the aerial part of Cirsium japonicum var. ussuriense (Regel) Kitam. ex Ohwi, suppresses the JAK/STAT and IRF-3 signaling pathway in LPS-stimulated RAW 264.7 macrophages. Chem. Biol. Interact. 2018, 293, 38-47. [CrossRef]

21. Walesiuk, A.; Nazaruk, J.; Braszko, J.J. Pro-cognitive effects of Cirsium rivulare extracts in rats. J. Ethnopharmacol. 2010, 129, 261-266. [CrossRef] [PubMed]

22. Jeong, G.H.; Park, E.K.; Kim, T.H. New anti-glycative flavonoids from Cirsium setidens with potent radical scavenging activities. Phytochem. Lett. 2018, 26, 115-119. [CrossRef]

23. Lu, Y.; Song, W.; Liang, X.; Wei, D.; Zhou, X. Chemical fingerprint and quantitative analysis of Cirsium setosum by LC. Chromatographia 2009, 70, 125-131. [CrossRef]

24. Sun, Q.; Chang, L.; Ren, Y.; Cao, L.; Sun, Y.; Du, Y.; Shi, X.; Wang, Q.; Zhang, L. Simultaneous analysis of 11 main active components in Cirsium setosum based on HPLC-ESI-MS/MS and combined with statistical methods. J. Sep. Sci. 2012, 35, 2897-2907. [CrossRef]

25. Wang, B.; Lv, D.; Huang, P.; Yan, F.; Liu, C.; Liu, H. Optimization, evaluation and identification of flavonoids in Cirsium setosum (Willd.) MB by using response surface methodology. J. Food Meas. Charact. 2019, 13, 1175-1184. [CrossRef]

26. Nugroho, A.; Lim, S.C.; Byeon, J.S.; Choi, J.S.; Park, H.J. Simultaneous quantification and validation of caffeoylquinic acids and flavonoids in Hemistepta lyrata and peroxynitrite-scavenging activity. J. Pharm. Biomed. Anal. 2013, 76, 139-144. [CrossRef] [PubMed]

27. Shin, K.H.; Kang, S.S.; Seo, E.A.; Shin, S.W. Isolation of aldose reductase inhibitors from the flowers of Chrysanthemum boreale. Arch. Pharm. Res. 1995, 18, 65-68. [CrossRef]

28. Han, A.R.; Kim, H.Y.; So, Y.; Nam, B.; Lee, I.S.; Nam, J.W.; Jo, Y.D.; Kim, S.H.; Kim, J.B.; Kang, S.Y.; et al. Quantification of antioxidant phenolic compounds in a new Chrysanthemum cultivar by high-performance liquid chromatography with diode array detection and electrospray ionization mass spectrometry. Int. J. Anal. Chem. 2017, 2017, 1-8. [CrossRef] 
29. Dasgupta, A. Antiinflammatory herbal supplements. In Translational Inflammation; Elsevier: Amsterdam, The Netherlands, 2019; pp. 69-91.

30. Wu, X.L.; Li, C.W.; Chen, H.M.; Su, Z.Q.; Zhao, X.N.; Chen, J.N.; Lai, X.P.; Zhang, X.J.; Su, Z.R. Anti-inflammatory effect of supercritical-carbon dioxide fluid extract from flowers and buds of Chrysanthemum indicum Linnén. Evid.-Based Complement. Altern. Med. 2013, 2013, 413237. [CrossRef] [PubMed]

31. He, J.; Wu, X.; Kuang, Y.; Wang, T.; Bi, K.; Li, Q. Quality assessment of Chrysanthemum indicum Flower by simultaneous quantification of six major ingredients using a single reference standard combined with HPLC fingerprint analysis. Asian J. Pharm. Sci. 2016, 11, 265-272. [CrossRef]

32. Seo, D.W.; Cho, Y.R.; Kim, W.; Eom, S.H. Phytochemical linarin enriched in the flower of Chrysanthemum indicum inhibits proliferation of A549 human alveolar basal epithelial cells through suppression of the Akt-dependent signaling pathway. J. Med. Food 2013, 16, 1086-1094. [CrossRef]

33. Kim, S.J.; Cho, H.I.; Kim, S.J.; Park, J.H.; Kim, J.S.; Kim, Y.H.; Lee, S.K.; Kwak, J.H.; Lee, S.M. Protective effect of linarin against D-galactosamine and lipopolysaccharide-induced fulminant hepatic failure. Eur. J. Pharmacol. 2014, 738, 66-73. [CrossRef] [PubMed]

34. Jiang, Y.; Ji, X.; Duan, L.; Ye, P.; Yang, J.; Zhan, R.; Chen, W.; Ma, D. Gene mining and identification of a flavone synthase II involved in flavones biosynthesis by transcriptomic analysis and targeted flavonoid profiling in Chrysanthemum indicum L. Ind. Crops Prod. 2019, 134, 244-256. [CrossRef]

35. Hwang, S.; Paek, J.; Lim, S. Simultaneous ultra performance liquid chromatography determination and antioxidant activity of linarin, luteolin, chlorogenic acid and apigenin in different parts of compositae species. Molecules 2016, 21, 1609. [CrossRef] [PubMed]

36. Qiaoshan, Y.; Suhong, C.; Minxia, S.; Wenjia, M.; Bo, L.; Guiyuan, L. Preparative purification of linarin extracts from Dendranthema indicum flowers and evaluation of its antihypertensive effect. Evid.-Based Complement. Altern. Med. 2014, 2014, 394276. [CrossRef]

37. Shin, H.J.; Lee, S.Y.; Kim, J.S.; Lee, S.; Choi, R.J.; Chung, H.S.; Kim, Y.S.; Kang, S.S. Sesquiterpenes and other constituents from Dendranthema zawadskii var. latilobum. Chem. Pharm. Bull. 2012, 60, 306-314. [CrossRef]

38. Singh, R.P.; Agrawal, P.; Yim, D.; Agarwal, C.; Agarwal, R. Acacetin inhibits cell growth and cell cycle progression, and induces apoptosis in human prostate cancer cells: Structure-activity relationship with linarin and linarin acetate. Carcinogenesis 2005, 26, 845-854. [CrossRef]

39. Li, J.; Lin, X.; Zhang, Y.; Liu, W.; Mi, X.; Zhang, J.; Su, J. Preparative purification of bioactive compounds from Flos Chrysanthemi indici and evaluation of its antiosteoporosis effect. Evid.-Based Complement. Altern. Med. 2016, 2016, 2587201. [CrossRef] [PubMed]

40. Pan, H.; Zhang, Q.; Cui, K.; Chen, G.; Liu, X.; Wang, L. Optimization of extraction of linarin from Flos Chrysanthemi indici by response surface methodology and artificial neural network. J. Sep. Sci. 2017, 40, 2062-2070. [CrossRef] [PubMed]

41. Wang, S.; Hao, L.-J.; Zhu, J.-J.; Wang, Z.-M.; Zhang, X.; Song, X. Comparative evaluation of Chrysanthemum Flos from different origins by HPLC-DAD-MS $\mathrm{n}$ and relative response factors. Food Anal. Methods 2015, 8, 40-51. [CrossRef]

42. Zhang, Q.; Li, J.; Wang, C.; Sun, W.; Zhang, Z.; Cheng, W. A gradient HPLC method for the quality control of chlorogenic acid, linarin and luteolin in Flos Chrysanthemi indici suppository. J. Pharm. Biomed. Anal. 2007, 43, 753-757. [CrossRef]

43. Jung, H.A.; Park, J.J.; Islam, M.N.; Jin, S.E.; Min, B.S.; Lee, J.H.; Sohn, H.S.; Choi, J.S. Inhibitory activity of coumarins from Artemisia capillaris against advanced glycation endproduct formation. Arch. Pharm. Res. 2012, 35, 1021-1035. [CrossRef]

44. Laskaris, G.G.; Gournelis, D.C.; Kokkalou, E. Phenolics of Picnomon acarna. J. Nat. Prod. 1995, 58, 1248-1250. [CrossRef]

45. Kokkini, S.; Karousou, R.; Hanlidou, E. HERBS I Herbs of the Labiatae. In Encyclopedia of Food Sciences and Nutrition; Elsevier: Amsterdam, The Netherlands, 2003; pp. 3082-3090.

46. Oinonen, P.P.; Jokela, J.K.; Hatakka, A.I.; Vuorela, P.M. Linarin, a selective acetylcholinesterase inhibitor from Mentha arvensis. Fitoterapia 2006, 77, 429-434. [CrossRef]

47. Salin, O.; Törmäkangas, L.; Leinonen, M.; Saario, E.; Hagström, M.; Ketola, R.A.; Saikku, P.; Vuorela, H.; Vuorela, P.M. Corn mint (Mentha arvensis) extract diminishes acute Chlamydia pneumoniae infection in vitro and in vivo. J. Agric. Food Chem. 2011, 59, 12836-12842. [CrossRef]

48. Erenler, R.; Telci, İ.; Elmastas, M.; Aksit, H.; Gul, F.; Tufekci, A.R.; Demirtas, İ.; Kayir, Ö. Quantification of flavonoids isolated from Mentha spicata in selected clones of Turkish mint landraces. Turk. J. Chem. 2018, 42, 1695-1705. [CrossRef]

49. Dai, L.-M.; Zhao, C.-C.; Jin, H.-Z.; Tang, J.; Shen, Y.-H.; Li, H.-L.; Peng, C.-Y.; Zhang, W.-D. A new ferulic acid ester and other constituents from Dracocephalum peregrinum. Arch. Pharm. Res. 2008, 31, 1325-1329. [CrossRef] [PubMed]

50. Liu, J.; Peng, C.; Zhou, Q.-M.; Guo, L.; Liu, Z.-H.; Xiong, L. Alkaloids and flavonoid glycosides from the aerial parts of Leonurus japonicus and their opposite effects on uterine smooth muscle. Phytochemistry 2018, 145, 128-136. [CrossRef] [PubMed]

51. Monforte, M.T.; Lanuzza, F.; Pergolizzi, S.; Mondello, F.; Tzakou, O.; Galati, E.M. Protective effect of Calamintha officinalis Moench leaves against alcohol-induced gastric mucosa injury in rats. Macroscopic, histologic and phytochemical analysis. Phyther. Res. 2012, 26, 839-844. [CrossRef] [PubMed]

52. Marin, P.D.; Grayer, R.J.; Veitch, N.C.; Kite, G.C.; Harborne, J.B. Acacetin glycosides as taxonomic markers in Calamintha and Micromeria. Phytochemistry 2001, 58, 943-947. [CrossRef]

53. Tian, S.; Yu, Q.; Xin, L.; Zhou, Z.S.; Upur, H. Chemical fingerprinting by RP-RRLC-DAD and principal component analysis of Ziziphora clinopodioides from different locations. Nat. Prod. Commun. 2012, 7, 1181-1184. [CrossRef] 
54. Fan, P.; Hay, A.E.; Marston, A.; Hostettmann, K. Acetylcholinesterase-inhibitory activity of Linarin from Buddleja davidii, structureactivity relationships of related flavonoids, and chemical investigation of Buddleja nitida. Pharm. Biol. 2008, 46, 596-601. [CrossRef]

55. El-Domiaty, M.M.; Wink, M.; Aal, M.M.A.; Abou-Hashem, M.M.; Abd-Alla, R.H. Antihepatotoxic activity and chemical constituents of Buddleja asiatica Lour. Z. Naturforsch. C 2009, 64, 11-19. [CrossRef] [PubMed]

56. Estrada-Zúñiga, M.E.; Cruz-Sosa, F.; Rodríguez-Monroy, M.; Verde-Calvo, J.R.; Vernon-Carter, E.J. Phenylpropanoid production in callus and cell suspension cultures of Buddleja cordata Kunth. Plant. Cell Tissue Organ. Cult. 2009, 97, 39-47. [CrossRef]

57. Rodríguez-Zaragoza, S.; Ordaz, C.; Avila, G.; Muñoz, J.L.; Arciniegas, A.; De Vivar, A.R. In vitro evaluation of the amebicidal activity of Buddleia cordata (Loganiaceae, H.B.K.) on several strains of Acanthamoeba. J. Ethnopharmacol. 1999, 66, 327-334. [CrossRef]

58. Kim, Y.H.; Lee, Y.S.; Choi, E.M. Linarin isolated from Buddleja officinalis prevents hydrogen peroxide-induced dysfunction in osteoblastic MC3T3-E1 cells. Cell. Immunol. 2011, 268, 112-116. [CrossRef]

59. Sun, M.; Luo, Z.; Liu, Y.; Yang, R.; Lu, L.; Yu, G.; Ma, X.; Liu, A.; Guo, Y.; Zhao, H. Identification of the major components of Buddleja officinalis extract and their metabolites in rat urine by UHPLC-LTQ-orbitrap. J. Food Sci. 2016, 81, H2587-H2596. [CrossRef]

60. Tai, B.H.; Jung, B.Y.; Cuong, N.M.; Linh, P.T.; Tung, N.H.; Nhiem, N.X.; Huong, T.T.; Anh, N.T.; Kim, J.A.; Kim, S.K.; et al. Total peroxynitrite scavenging capacity of phenylethanoid and flavonoid glycosides from the flowers of Buddleja officinalis. Biol. Pharm. Bull. 2009, 32, 1952-1956. [CrossRef]

61. Avila Acevedo, J.G.; Castañeda, C.M.C.; Benitez, F.J.C.; Durán, D.A.; Barroso, V.R.; Martínez, C.G.; Muñoz, L.J.L.; Martínez, C.A.; Romo de Vivar, A. Photoprotective activity of Buddleja scordioides. Fitoterapia 2005, 76, 301-309. [CrossRef]

62. Otsuka, H. Isolation of isolinariins A and B, new flavonoid glycosides from Linaria japonica. J. Nat. Prod. 1992, 55, 1252-1255. [CrossRef]

63. Vrchovská, V.; Spilková, J.; Valentão, P.; Sousa, C.; Andrade, P.B.; Seabra, R.M. Assessing the antioxidative properties and chemical composition of Linaria vulgaris infusion. Nat. Prod. Res. 2008, 22, 735-746. [CrossRef]

64. Aydoğrdu, İ.; Zihnioğrlu, F.; Karayildirim, T.; Gülcemal, D.; Alankuş-Çalışkan, Ö.; Bedir, E. $\alpha$-glucosidase inhibitory constituents of Linaria kurdica subsp. eriocalyx. Nat. Prod. Commun. 2010, 5, 841-844. [CrossRef]

65. Leslie Gunatilaka, A.; Sotheeswaran, S.; Balasubramaniam, S.; Indumathie Chandrasekara, A.; Badra Sriyani, H. Linarin, a flavone glycoside from Exacum macranthum. Planta Med. 1980, 39, 66-72. [CrossRef]

66. Zhou, Y.; Wang, Y.; Wang, R.; Guo, F.; Yan, C. Two-dimensional liquid chromatography coupled with mass spectrometry for the analysis of Lobelia chinensis Lour. using an ESI/APCI multimode ion source. J. Sep. Sci. 2008, 31, 2388-2394. [CrossRef]

67. Wang, T.; Xiao, J.; Hou, H.; Li, P.; Yuan, Z.; Xu, H.; Liu, R.; Li, Q.; Bi, K. Development of an ultra-fast liquid chromatographytandem mass spectrometry method for simultaneous determination of seven flavonoids in rat plasma: Application to a comparative pharmacokinetic investigation of Ginkgo biloba extract and single pure ginkgo. J. Chromatogr. B 2017, 1060, $173-181$. [CrossRef]

68. El-Hagrassi, A.M.; Ali, M.M.; Osman, A.F.; Shaaban, M. Phytochemical investigation and biological studies of Bombax malabaricum flowers. Nat. Prod. Res. 2011, 25, 141-151. [CrossRef] [PubMed]

69. Zhang, W.-K.; Xu, J.-K.; Zhang, L.; Du, G.-H. Flavonoids from the bran of Avena sativa. Chin. J. Nat. Med. 2012, 10, 110-114. [CrossRef]

70. Ina, H.; Iida, H. Linarin monoacetate from Thalictrum aquilegifolium. Phytochemistry 1981, 20, 1176-1177. [CrossRef]

71. Ma, B.-X.; Meng, X.-S.; Tong, J.; Ge, L.-L.; Zhou, G.; Wang, Y.-W. Protective effects of Coptis chinensis inflorescence extract and linarin against carbon tetrachloride-induced damage in HepG2 cells through the MAPK/Keap1-Nrf2 pathway. Food Funct. 2018, 9, 2353-2361. [CrossRef]

72. Rios, M.Y.; Córdova-Albores, L.C.; Ramírez-Cisneros, M.Á.; King-DÍaz, B.; Lotina-Hennsen, B.; Rivera, I.L.; Miranda-Sánchez, D. Phytotoxic potential of Zanthoxylum affine and its major compound linarin as a possible natural herbicide. ACS Omega 2018, 3, 14779-14787. [CrossRef] [PubMed]

73. Martins, G.R.; da Fonseca, T.S.; Martínez-Fructuoso, L.; Simas, R.C.; Silva, F.T.; Salimena, F.R.G.; Alviano, D.S.; Alviano, C.S.; Leitão, G.G.; Pereda-Miranda, R.; et al. Antifungal phenylpropanoid glycosides from Lippia rubella. J. Nat. Prod. 2019, 82, 566-572. [CrossRef]

74. Liu, S.; Luo, X.; Li, D.; Zhang, J.; Qiu, D.; Liu, W.; She, L.; Yang, Z. Tumor inhibition and improved immunity in mice treated with flavone from Cirsium japonicum DC. Int. Immunopharmacol. 2006, 6, 1387-1393. [CrossRef]

75. Byun, J.-H.; Choi, C.-W.; Jang, M.-J.; Lim, S.H.; Han, H.J.; Choung, S.-Y. Anti-osteoarthritic mechanisms of Chrysanthemum zawadskii var. latilobum in MIA-induced osteoarthritic rats and interleukin-1 $\beta$-induced SW1353 human chondrocytes. Medicina (B. Aires). 2020, 56, 685. [CrossRef]

76. Chen, X.; Zhang, S.; Xuan, Z.; Ge, D.; Chen, X.; Zhang, J.; Wang, Q.; Wu, Y.; Liu, B. The phenolic fraction of Mentha haplocalyx and its constituent linarin ameliorate inflammatory response through inactivation of NF-kB and MAPKs in lipopolysaccharide-induced RAW264.7 cells. Molecules 2017, 22, 811. [CrossRef]

77. Zhang, X.-M.; An, D.-Q.; Guo, L.-L.; Yang, N.-H.; Zhang, H. Identification and screening of active components from Ziziphora clinopodioides Lam. in regulating autophagy. Nat. Prod. Res. 2019, 33, 2549-2553. [CrossRef] 
78. Navarrete, A.; Avula, B.; Choi, Y.-W.; Khan, I.A. Chemical fingerprinting of valeriana species: Simultaneous determination of valerenic acids, flavonoids, and phenylpropanoids using liquid chromatography with ultraviolet detection. J. AOAC Int. 2006, 89, 8-15. [CrossRef]

79. Srivastava, S.; Ahmad, R.; Khare, S.K. Alzheimer's disease and its treatment by different approaches: A review. Eur. J. Med. Chem. 2021, 216, 113320. [CrossRef]

80. Feng, X.; Wang, X.; Liu, Y.; Di, X. Linarin inhibits the acetylcholinesterase activity in-vitro and ex-vivo. Iran. J. Pharm. Res. 2015, 14, 949-954. [CrossRef] [PubMed]

81. Pan, H.; Zhang, J.; Wang, Y.; Cui, K.; Cao, Y.; Wang, L.; Wu, Y. Linarin improves the dyskinesia recovery in Alzheimer's disease zebrafish by inhibiting the acetylcholinesterase activity. Life Sci. 2019, 222, 112-116. [CrossRef] [PubMed]

82. Santos, G.; Giraldez-Alvarez, L.D.; Ávila-Rodriguez, M.; Capani, F.; Galembeck, E.; Neto, A.G.; Barreto, G.E.; Andrade, B. SUR1 receptor interaction with hesperidin and linarin predicts possible mechanisms of action of Valeriana officinalis in Parkinson. Front. Aging Neurosci. 2016, 8, 1-12. [CrossRef]

83. Jang, M.; Kim, K.-H.; Kim, G.-H. Antioxidant capacity of thistle (Cirsium japonicum) in various drying methods and their protection effect on neuronal PC12 cells and Caenorhabditis elegans. Antioxidants 2020, 9, 200. [CrossRef] [PubMed]

84. Zeng, J.; Hu, W.; Li, H.; Liu, J.; Zhang, P.; Gu, Y.; Yu, Y.; Wang, W.; Wei, Y. Purification of linarin and hesperidin from Mentha haplocalyx by aqueous two-phase flotation coupled with preparative HPLC and evaluation of the neuroprotective effect of linarin. J. Sep. Sci. 2021, 44, 2496-2503. [CrossRef]

85. Fernández, S.P.; Wasowski, C.; Loscalzo, L.M.; Granger, R.E.; Johnston, G.A.R.; Paladini, A.C.; Marder, M. Central nervous system depressant action of flavonoid glycosides. Eur. J. Pharmacol. 2006, 539, 168-176. [CrossRef]

86. Nugroho, A.; Lim, S.C.; Choi, J.; Park, H.J. Identification and quantification of the sedative and anticonvulsant flavone glycoside from Chrysanthemum boreale. Arch. Pharm. Res. 2013, 36, 51-60. [CrossRef]

87. Li, J.; Hao, L.; Wu, J.; Zhang, J.; Su, J. Linarin promotes osteogenic differentiation by activatingthe BMP-2/RUNX2 pathway via protein kinase A signaling. Int. J. Mol. Med. 2016, 37, 901-910. [CrossRef] [PubMed]

88. Kim, S.-I.; Kim, Y.H.; Kang, B.G.; Kang, M.K.; Lee, E.J.; Kim, D.Y.; Oh, H.; Oh, S.Y.; Na, W.; Lim, S.S.; et al. Linarin and its aglycone acacetin abrogate actin ring formation and focal contact to bone matrix of bone-resorbing osteoclasts through inhibition of $\alpha \mathrm{v} \beta 3$ integrin and core-linked CD44. Phytomedicine 2020, 79, 153351. [CrossRef] [PubMed]

89. Qi, W.; Chen, Y.; Sun, S.; Xu, X.; Zhan, J.; Yan, Z.; Shang, P.; Pan, X.; Liu, H. Inhibiting TLR4 signaling by linarin for preventing inflammatory response in osteoarthritis. Aging (Albany NY) 2021, 13, 5369-5382. [CrossRef]

90. Yu, Q.; Li, X.; Cao, X. Linarin could protect myocardial tissue from the injury of Ischemia-reperfusion through activating Nrf-2. Biomed. Pharmacother. 2017, 90,1-7. [CrossRef] [PubMed]

91. Chengyu, Y.; Long, Z.; Bin, Z.; Hong, L.; Xuefei, S.; Congjuan, L.; Caixia, C.; Yan, X. Linarin protects the kidney against ischemia/reperfusion injury via the inhibition of bioactive ETS2/IL-12. Biol. Pharm. Bull. 2021, 44, 25-31. [CrossRef]

92. Tian, D.; Yang, Y.; Yu, M.; Han, Z.Z.; Wei, M.; Zhang, H.W.; Jia, H.M.; Zou, Z.M. Anti-inflammatory chemical constituents of Flos Chrysanthemi indici determined by UPLC-MS/MS integrated with network pharmacology. Food Funct. 2020, 11, 6340-6351. [CrossRef] [PubMed]

93. Hu, L.; Chen, Y.; Chen, T.; Huang, D.; Li, S.; Cui, S. A systematic study of mechanism of Sargentodoxa cuneata and Patrinia scabiosifolia against pelvic inflammatory disease with dampness-heat stasis syndrome via network pharmacology approach. Front. Pharmacol. 2020, 11, 1856. [CrossRef]

94. Acevedo, J.G.A.; Espinosa González, A.M.; y Campos, D.M.D.M.; Benitez Flores, J.d.C.; Delgado, T.H.; Maya, S.F.; Contreras, J.C.; López, J.L.M.; García Bores, A.M. Photoprotection of Buddleja cordata extract against UVB-induced skin damage in SKH-1 hairless mice. BMC Complement. Altern. Med. 2014, 14, 1-9. [CrossRef]

95. Jung, C.-H.; Han, A.-R.; Chung, H.-J.; Ha, I.-H.; Um, H.-D. Linarin inhibits radiation-induced cancer invasion by downregulating MMP-9 expression via the suppression of NF-кB activation in human non-small-cell lung cancer A549. Nat. Prod. Res. 2019, 33, 3582-3586. [CrossRef]

96. Peng, C.; Stewart, A.G.; Woodman, O.L.; Ritchie, R.H.; Qin, C.X. Non-alcoholic steatohepatitis: A review of its mechanism, models and medical treatments. Front. Pharmacol. 2020, 11, 1864. [CrossRef]

97. Zhuang, Z.J.; Shan, C.W.; Li, B.; Pang, M.X.; Wang, H.; Luo, Y.; Liu, Y.L.; Song, Y.; Wang, N.N.; Chen, S.H.; et al. Linarin enriched extract attenuates liver injury and inflammation induced by high-fat high-cholesterol diet in rats. Evid.-Based Complement. Altern. Med. 2017, 2017, 4701570. [CrossRef]

98. Kim, Y.J.; Kim, H.K.; Lee, H.S. Hypoglycemic effect of standardized Chrysanthemum zawadskii ethanol extract in high-fat $\operatorname{diet/streptozotocin-induced~diabetic~mice~and~rats.~Food~Sci.~Biotechnol.~2018,~27,~1771-1779.~[CrossRef]~[PubMed]~}$

99. Kim, Y.-J.; Kim, S.-E.; Lee, H.S.; Hong, S.-Y.; Kim, S.-E.; Kim, Y.J.; Lee, J.H.; Park, S.J.; Kim, J.H.; Park, Y.-J.; et al. Comparison of linarin content and biological activity in ethanol extraction of Chrysanthemum zawadskii. J. Korean Soc. Food Sci. Nutr. 2016, 45, 1414-1421. [CrossRef]

100. Chenafa, H.; Mesli, F.; Daoud, I.; Achiri, R.; Ghalem, S.; Neghra, A. In silico design of enzyme $\alpha$-amylase and $\alpha$-glucosidase inhibitors using molecular docking, molecular dynamic, conceptual DFT investigation and pharmacophore modelling. J. Biomol. Struct. Dyn. 2021, 1-22. [CrossRef] [PubMed]

101. Martínez-Vázquez, M.; Ramírez Apan, T.O.; Aguilar, M.H.; Bye, R. Analgesic and antipyretic activities of an aqueous extract and of the flavone linarin of Buddleia cordata. Planta Med. 1996, 62, 137-140. [CrossRef] 
102. Sándor, Z.; Mottaghipisheh, J.; Veres, K.; Hohmann, J.; Bencsik, T.; Horváth, A.; Kelemen, D.; Papp, R.; Barthó, L.; Csupor, D. Evidence supports tradition: The in vitro effects of roman chamomile on smooth muscles. Front. Pharmacol. $2018,9,323$. [CrossRef]

103. Ghayur, M.N.; Khan, H.; Gilani, A.H. Antispasmodic, bronchodilator and vasodilator activities of (+)-catechin, a naturally occurring flavonoid. Arch. Pharm. Res. 2007, 30, 970-975. [CrossRef]

104. Mendel, M.; Chłopecka, M.; Dziekan, N.; Karlik, W. Antispasmodic effect of selected Citrus flavonoids on rat isolated jejunum specimens. Eur. J. Pharmacol. 2016, 791, 640-646. [CrossRef] [PubMed]

105. das Graças, C.; de Souza, M.; Cyrino, F.Z.; de Carvalho, J.J.; Blanc-Guillemaud, V.; Bouskela, E. Protective effects of Micronized Purified Flavonoid Fraction (MPFF) on a novel experimental model of chronic venous hypertension. Eur. J. Vasc. Endovasc. Surg. 2018, 55, 694-702. [CrossRef] [PubMed]

106. Chen, Y.; Zeng, L.; Yang, J.; Wang, Y.; Yao, F.; Wu, Y.; Wang, D.; Hu, Y.; Liu, J. Anti-DHAV-1 reproduction and immuno-regulatory effects of a flavonoid prescription on duck virus hepatitis. Pharm. Biol. 2017, 55, 1545-1552. [CrossRef] [PubMed]

107. Chen, Y.; Zeng, L.; Lu, Y.; Yang, Y.; Xu, M.; Wang, Y.; Liu, J. Treatment effect of a flavonoid prescription on duck virus hepatitis by its hepatoprotective and antioxidative ability. Pharm. Biol. 2017, 55, 198-205. [CrossRef]

108. Zarenezhad, E.; Farjam, M.; Iraji, A. Synthesis and biological activity of pyrimidines-containing hybrids: Focusing on pharmacological application. J. Mol. Struct. 2021, 1230, 129833. [CrossRef]

109. Yonekawa, M.; Shimizu, M.; Kaneko, A.; Matsumura, J.; Takahashi, H. Suppression of R5-type of HIV-1 in CD4 + NKT cells by $\mathrm{V} \delta 1+\mathrm{T}$ cells activated by flavonoid glycosides, hesperidin and linarin. Sci. Rep. 2019, 9, 1-12. [CrossRef] [PubMed]

110. Xu, L.; Jiang, W.; Jia, H.; Zheng, L.; Xing, J.; Liu, A.; Du, G. Discovery of multitarget-directed ligands against influenza a virus from compound yizhihao through a predictive system for compound-protein interactions. Front. Cell. Infect. Microbiol. 2020, 10, 16. [CrossRef]

111. Fedotcheva, T.A.; Fedotcheva, N.I.; Shimanovsky, N.L. Progestins as anticancer drugs and chemosensitizers, new targets and applications. Pharmaceutics 2021, 13, 1616. [CrossRef]

112. Talib, W.H.; Alsayed, A.R.; Barakat, M.; Abu-Taha, M.I.; Mahmod, A.I. Targeting drug chemo-resistance in cancer using natural products. Biomedicines 2021, 9, 1353. [CrossRef]

113. Ailioaie, L.M.; Ailioaie, C.; Litscher, G. Latest innovations and nanotechnologies with curcumin as a nature-inspired photosensitizer applied in the photodynamic therapy of cancer. Pharmaceutics 2021, 13, 1562. [CrossRef] [PubMed]

114. Thaipong, K.; Boonprakob, U.; Crosby, K.; Cisneros-Zevallos, L.; Hawkins Byrne, D. Comparison of ABTS, DPPH, FRAP, and ORAC assays for estimating antioxidant activity from guava fruit extracts. J. Food Compos. Anal. 2006, 19, 669-675. [CrossRef]

115. Zhen, Z.G.; Ren, S.H.; Ji, H.M.; Ma, J.H.; Ding, X.M.; Feng, F.Q.; Chen, S.L.; Zou, P.; Ren, J.R.; Jia, L. Linarin suppresses glioma through inhibition of NF-kB/p65 and up-regulating p53 expression in vitro and in vivo. Biomed. Pharmacother. 2017, 95, 363-374. [CrossRef]

116. Alqahtani, M.S.; Al-Yousef, H.M.; Alqahtani, A.S.; Tabish Rehman, M.; AlAjmi, M.F.; Almarfidi, O.; Amina, M.; Alshememry, A.; Syed, R. Preparation, characterization, and in vitro-in silico biological activities of Jatropha pelargoniifolia extract loaded chitosan nanoparticles. Int. J. Pharm. 2021, 606, 120867. [CrossRef]

117. Sharif Siam, M.K.; Sarker, A.; Sayeem, M.M.S. In silico drug design and molecular docking studies targeting Akt1 (RAC-alpha serine/threonine-protein kinase) and Akt2 (RAC-beta serine/threonine-protein kinase) proteins and investigation of CYP (cytochrome P450) inhibitors against MAOB (monoamine oxidase B) for OSCC (oral squamous cell carcinoma) treatment. J. Biomol. Struct. Dyn. 2021, 39, 6467-6479. [CrossRef]

118. De La Peña, J.B.I.; Kim, C.A.; Lee, H.L.; Yoon, S.Y.; Kim, H.J.; Hong, E.Y.; Kim, G.H.; Ryu, J.H.; Lee, Y.S.; Kim, K.M.; et al. Luteolin mediates the antidepressant-like effects of Cirsium japonicum in mice, possibly through modulation of the GABAA receptor. Arch. Pharm. Res. 2014, 37, 263-269. [CrossRef]

119. Bouazzaoui, A.; Abdellatif, A.A.H.; Al-Allaf, F.A.; Bogari, N.M.; Al-Dehlawi, S.; Qari, S.H. Strategies for vaccination: Conventional vaccine approaches versus new-generation strategies in combination with adjuvants. Pharmaceutics 2021, 13, 140. [CrossRef] [PubMed]

120. Sheikh, A.B.; Pal, S.; Javed, N.; Shekhar, R. COVID-19 vaccination in developing nations: Challenges and opportunities for innovation. Infect. Dis. Rep. 2021, 13, 429-436. [CrossRef] [PubMed]

121. Jirjees, F.; Saad, A.K.; Al Hano, Z.; Hatahet, T.; Al Obaidi, H.; Dallal Bashi, Y.H. COVID-19 treatment guidelines: Do they really reflect best medical practices to manage the pandemic? Infect. Dis. Rep. 2021, 13, 259-284. [CrossRef]

122. Shah, S.A.A.; ul Hassan, S.S.; Bungau, S.; Si, Y.; Xu, H.; Rahman, M.H.; Behl, T.; Gitea, D.; Pavel, F.-M.; Corb Aron, R.A.; et al. Chemically diverse and biologically active secondary metabolites from marine Phylum chlorophyta. Mar. Drugs 2020, 18, 493. [CrossRef] [PubMed]

123. Mahmoudi, S.; Balmeh, N.; Mohammadi, N.; Sadeghian-Rizi, T. The novel drug discovery to combat COVID-19 by repressing important virus proteins involved in pathogenesis using medicinal herbal compounds. Avicenna J. Med. Biotechnol. 2021, 13, 108. [CrossRef]

124. Egert, S.; Rimbach, G. Which sources of flavonoids: Complex diets or dietary supplements? Adv. Nutr. 2011, 2, 8-14. [CrossRef] [PubMed]

125. Slámová, K.; Kapešová, J.; Valentová, K. “Sweet flavonoids”: Glycosidase-catalyzed modifications. Int. J. Mol. Sci. $2018,19,2126$. [CrossRef] 
126. Fernández, S.; Wasowski, C.; Paladini, A.C.; Marder, M. Sedative and sleep-enhancing properties of linarin, a flavonoid-isolated from Valeriana officinalis. Pharmacol. Biochem. Behav. 2004, 77, 399-404. [CrossRef] [PubMed]

127. Chari, V.M.; Jordan, M.; Wagner, H.; Thies, P.W. A 13C-NMR study of the structure of an acyllinarin from Valeriana wallichii. Phytochemistry 1977, 16, 1110-1112. [CrossRef]

128. Martínez-Vázquez, M.; Ramírez Apan, T.O.; Lastra, A.L.; Bye, R. A comparative study of the analgesic and anti-inflammatory activities of pectolinarin isolated from Cirsium subcoriaceum and linarin isolated from Buddleia cordata. Planta Med. 1998, 64, 134-137. [CrossRef] [PubMed]

129. Han, S.; Sung, K.; Yim, D.; Lee, S.; Lee, C.; Ha, N.; Kim, K. The effect of linarin on LPS-induced cytokine production and nitric oxide inhibition in murine macrophages cell line RAW264.7. Arch. Pharm. Res. 2002, 25, 170-177. [CrossRef] [PubMed]

130. Shim, S.; Kang, H.; Sun, H.; Lee, Y.; Park, J.; Chun, S. Isolation and identification of flavonoids from Gujeolcho (Chrysanthemum zawadskii var. latilobum) as inhibitor of histamine release. Food Sci. Biotechnol. 2012, 21, 613-617. [CrossRef]

131. Xu, Z.; Sun, X.; Lan, Y.; Han, C.; Zhang, Y.; Chen, G. Linarin sensitizes tumor necrosis factor-related apoptosis (TRAIL)-induced ligand-triggered apoptosis in human glioma cells and in xenograft nude mice. Biomed. Pharmacother. 2017, 95, 1607-1618. [CrossRef] [PubMed]

132. Lv, G.-Y.; Zhang, Y.-P.; Gao, J.-L.; Yu, J.-J.; Lei, J.; Zhang, Z.-R.; Li, B.; Zhan, R.-J.; Chen, S.-H. Combined antihypertensive effect of luteolin and buddleoside enriched extracts in spontaneously hypertensive rats. J. Ethnopharmacol. 2013, 150, 507-513. [CrossRef] [PubMed]

133. Kim, B.; Lee, J.H.; Seo, M.J.; Eom, S.H.; Kim, W. Linarin down-regulates phagocytosis, pro-inflammatory cytokine production, and activation marker expression in RAW264.7 macrophages. Food Sci. Biotechnol. 2016, 25, 1437-1442. [CrossRef] [PubMed]

134. Kim, A.R.; Kim, H.S.; Kim, D.K.; Lee, J.H.; Yoo, Y.H.; Kim, J.Y.; Park, S.K.; Nam, S.T.; Kim, H.W.; Park, Y.H.; et al. The extract of Chrysanthemum zawadskii var. latilobum ameliorates collagen-induced arthritis in mice. Evid.-Based Complement. Altern. Med. 2016, 2016, 3915013. [CrossRef]

135. Han, X.; Wu, Y.I.-C.; Meng, M.; Sun, Q.-S.; Gao, S.-M.; Sun, H. Linarin prevents LPS-induced acute lung injury by suppressing oxidative stress and inflammation via inhibition of TXNIP/NLRP3 and NF-kB pathways. Int. J. Mol. Med. 2018, 42, 1460-1472. [CrossRef]

136. Xie, G.; Yang, J.; Wei, X.; Xu, Q.; Qin, M. Separation of acteoside and linarin from Buddlejae Flos by high-speed countercurrent chromatography and their anti-inflammatory activities. J. Sep. Sci. 2020, 48, 1-8. [CrossRef]

137. Benitez, F.J.C.; Acevedo, J.G.A.; Castan, C.M.C.; Dura, D.A.; Barroso, V.R.; Mart1, C.G.; Vivar, A.R. De Photoprotective activity of Buddleja scordioides. Fitoterapia 2005, 76, 301-309. [CrossRef]

138. Chow, N.; Fretz, M.; Hamburger, M.; Butterweck, V. Telemetry as a tool to measure sedative effects of a valerian root extract and its single constituents in mice. Planta Med. 2011, 77, 795-803. [CrossRef] [PubMed] 